Lithologic Properties of Carbonate-Rock Aquifers at Five Test Wells in the Coyote Spring Valley Area, Southern Nevada, as Determined From Geophysical Logs

By David L. Berger

U.S. GEOLOGICAL SURVEY

Water-Resources Investigation Report 91-4167

Prepared in cooperation with the

STATE OF NEVADA, the

LAS VEGAS VALLEY WATER DISTRICT, and the

U.S. BUREAU OF RECLAMATION

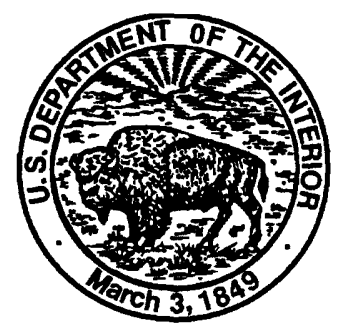

Carson City, Nevada 1992 


\section{CONTENTS}

Page

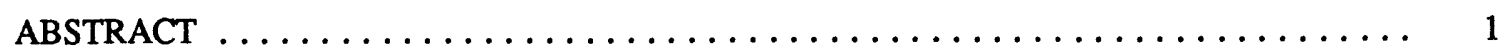

INTRODUCTION $\ldots \ldots \ldots \ldots \ldots \ldots \ldots \ldots \ldots \ldots \ldots \ldots \ldots \ldots \ldots \ldots$

GEOPHYSICAL LOGGING METHODS $\ldots \ldots \ldots \ldots \ldots \ldots \ldots \ldots \ldots \ldots \ldots \ldots$

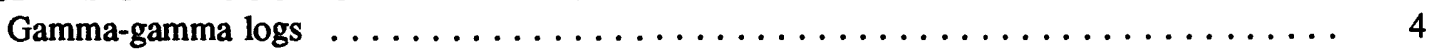

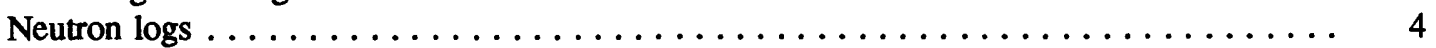

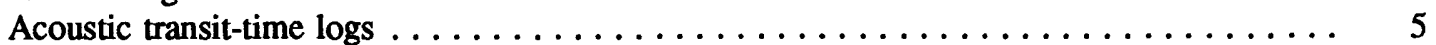

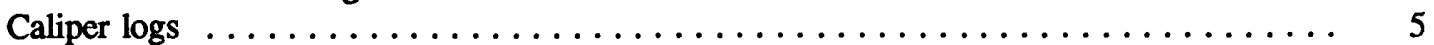

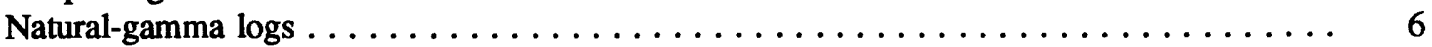

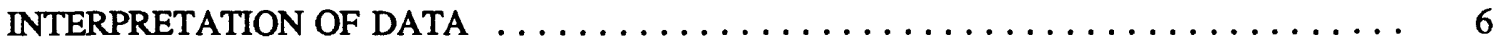

LITHOLOGIC PROPERTIES FROM LOG ANALYSIS $\ldots \ldots \ldots \ldots \ldots \ldots \ldots \ldots$

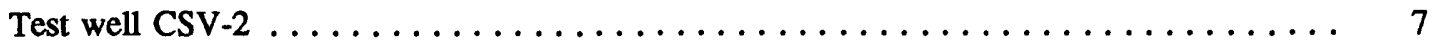

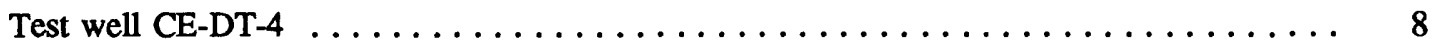

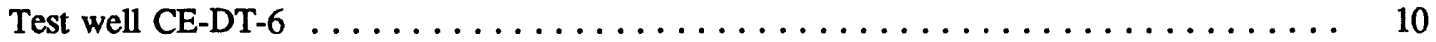

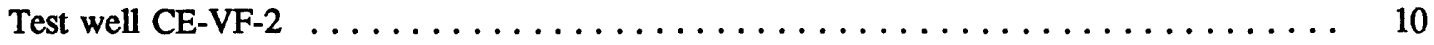

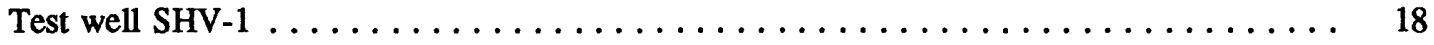

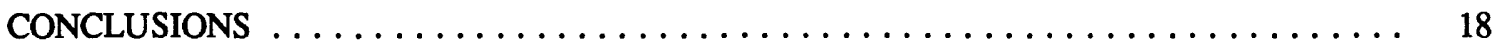

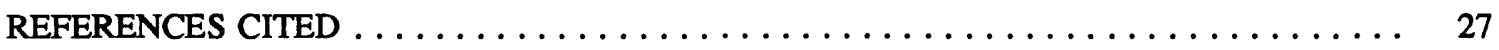

\section{ILLUSTRATIONS}

Figure 1. Map showing location of study area, test-well sites, and line of section

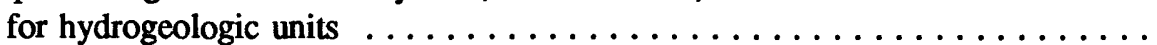

2. Generalized section of hydrogeologic units in study area ............. 3

3. Acoustic, caliper, and natural-gamma logs and eight zone depths from

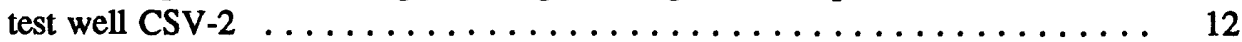

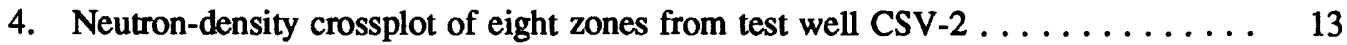

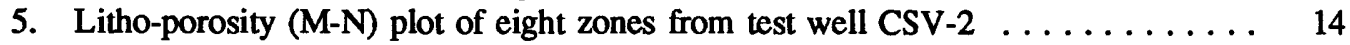

6. Caliper and natural-gamma logs and seven zone depths from test well CE-DT-4 . 15

7. Neutron-density crossplot of seven zones from test well CE-DT-4 $\ldots \ldots \ldots \ldots .16$

8. Litho-porosity (M-N) plot of seven zones from test well CE-DT-4 . . . . . . . 17

9. Caliper $\log$ and eight zone depths from test well CE-DT-6 . . . . . . . . . 19

10. Acoustic-density crossplot of eight zones from test well CE-DT-6 . . . . . . 20

11. Acoustic, caliper, and natural-gamma logs and eleven zone depths from test

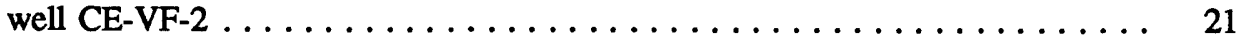

12. Neutron-density crossplot of eleven zones from test well CE-VF-2 . . . . . . 22

13. Litho-porosity (M-N) plot of eleven zones from test well CE-VF-2 . . . . . . 23

14. Caliper and natural-gamma logs and nine zone depths from test well SHV-1 . . . 24

15. Neutron-density crossplot of nine zones from test well SHV-1 . . . . . . 25

16. Litho-porosity (M-N) plot of nine zones from test well SHV-1 . . . . . . 26 


\section{TABLES}

Page

Table 1. Test-well information and depth to ground-water level $\ldots \ldots \ldots \ldots \ldots \ldots$

2. Average geophysical $\log$ data and litho-porosity $(\mathrm{M}$ and $\mathrm{N}$ ) values $\ldots \ldots \ldots . . .9$

3. Matrix density, total porosity, and matrix mineral composition interpreted from geophysical $\log$ analysis $\ldots \ldots \ldots \ldots \ldots \ldots \ldots \ldots \ldots$

\section{CONVERSION FACTORS, VERTICAL DATUM, AND ABBREVIATIONS}

\begin{tabular}{|c|c|c|}
\hline Multiply & By & To Obtain \\
\hline inch (in.) & 2.54 & centimeter $(\mathrm{cm})$ \\
\hline foot $(f t)$ & 0.3048 & meter (m) \\
\hline mile (mi) & 1.609 & kilometer $(\mathrm{km})$ \\
\hline $\begin{array}{l}\text { foot per second } \\
(\mathrm{ft} / \mathrm{s})\end{array}$ & 0.3048 & $\begin{array}{l}\text { meter per second } \\
(\mathrm{m} / \mathrm{s})\end{array}$ \\
\hline $\begin{array}{l}\text { microsecond per foot } \\
(\mu \mathrm{s} / \mathrm{ft})\end{array}$ & 3.28 & $\begin{array}{l}\text { microsecond per meter } \\
(\mu \mathrm{s} / \mathrm{m})\end{array}$ \\
\hline
\end{tabular}

\section{SEA LEVEL}

In this report, "sea level" refers to the National Geodetic Vertical Datum of 1929 (NGVD of 1929 , formerly called "Sea Level Datum of 1929 "), which is derived from a general adjustment of the first order leveling networks of both the United States and Canada.

The following terms and abbreviations also are used in this report: gram per cubic centimeter $\left(\mathrm{g} / \mathrm{cm}^{3}\right)$ and counts per second (cps). 


\title{
Lithologic Properties of Carbonate-Rock Aquifers at Five Test Wells in the Coyote Spring Valley Area, Southern Nevada, as Determined From Geophysical Logs
}

\author{
By
}

David L. Berger

\begin{abstract}
Regional ground-water flow systems in the carbonate-rock aquifers in southern Nevada were evaluated as potential sources for water supply as part of the Nevada Carbonate Aquifers Program. Geophysical log analyses indicated that the test wells penetrate carbonate rocks, which vary in composition from limestone to dolomite and include mixtures of both. Calcite was found to be the predominant matrix mineral and shales made up only a small percentage of the overall rock. Bulk-density measurements averaged 2.65 grams per cubic centimeter and the matrix density estimates averaged 2.76 grams per cubic centimeter. Increased amounts of silica in the matrix mineralogy were associated with greater total porosity values. The log analyses indicated an average of 4.7 percent porosity for 43 zones in the test wells.
\end{abstract}

\section{INTRODUCTION}

Paleozoic carbonate-rock aquifers in southern Nevada contain regional ground-water flow systems that were evaluated as potential sources for water supply. As part of the Nevada Carbonate Aquifers Program (NCAP), these investigations were made in cooperation with the State of Nevada, the Las Vegas Valley Water District, and the U.S. Bureau of Reclamation. The program included test-well drilling as well as collection of geologic, geophysical, and hydrologic data. This report describes the application and results of borehole geophysical log analyses from five test wells that penetrated the carbonate-rock aquifers. In order to evaluate the carbonate-rock aquifers, in-place measurement of lithologic properties was needed.

Lithologic properties were determined using standard geophysical log-analysis techniques adapted from the petroleum industry. In-place measurements of bulk density, neutron porosity, and acoustic transit time were used to estimate matrix density and total porosity from selected zones of the saturated part of each test well. The identification and composition of the matrix mineralogy that make up the carbonate rock in each zone were determined by graphical techniques and log responses. The lithology in zones that exhibited secondary porosity development was identified and qualitatively interpreted from lithologic crossplots.

The study area is in the southern part of the Great Basin region of southern Nevada (fig. 1). The topography is controlled by the horst and graben structure characteristic of the Basin and Range Province. Thick sequences of Paleozoic sedimentary rock make up the mountain ranges and underlie intervening basins that are partly filled with Tertiary and Quaternary sedimentary deposits. A generalized hydrogeologic section for the northern part of the study area is shown in figure 2. The location of the section is shown in figure 1. Ground water is found in both the carbonate-rock and basin-fill aquifers. These two types of aquifers are not always hydraulically connected at a local scale. Older noncarbonate rocks generally have low transmissivities and act as barriers to ground-water flow, as do the crystalline basement rocks (Dettinger, 1987). 


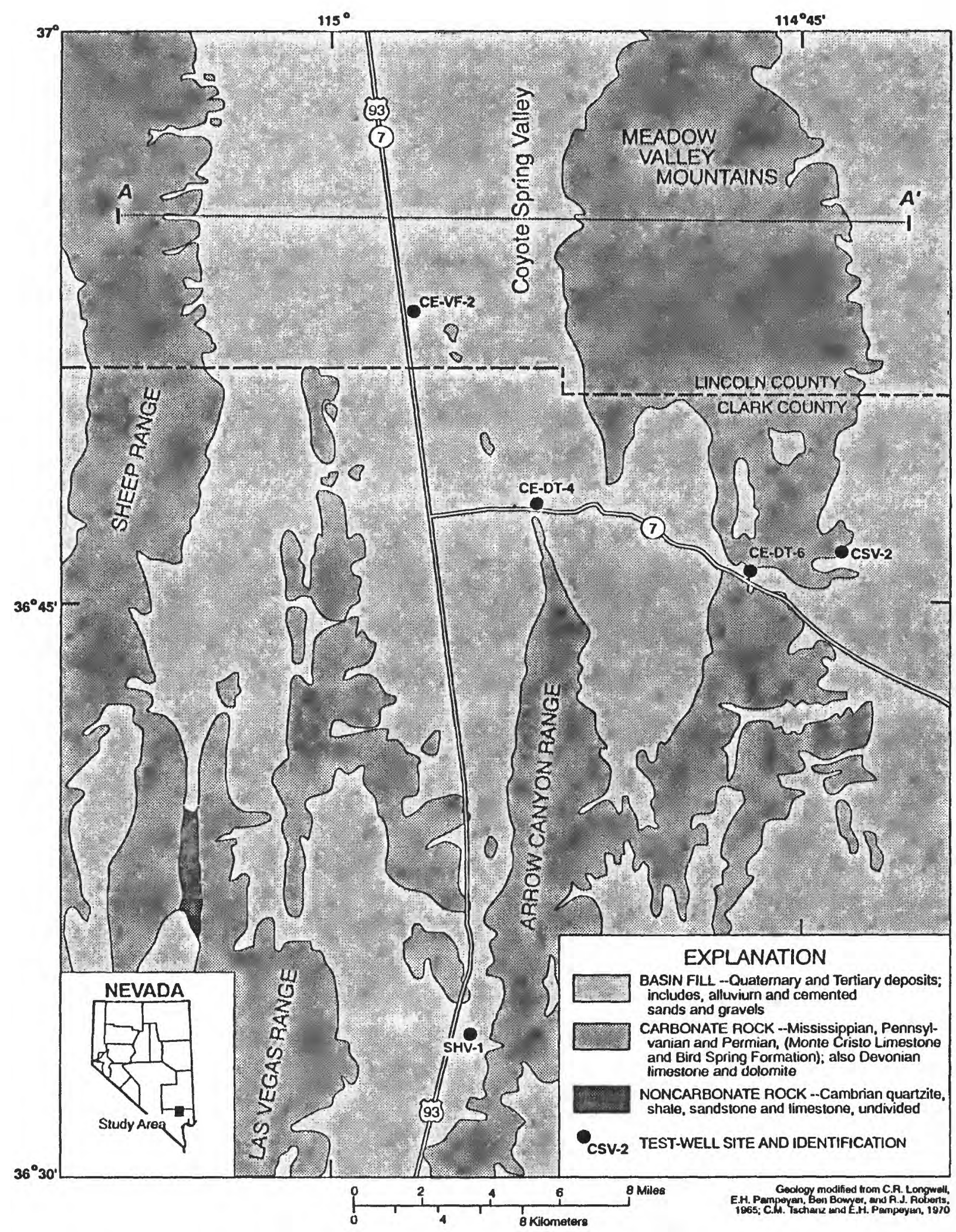

FIGURE 1. --Location of study area, test-well sites, and line of section for hydrogeologic units. 


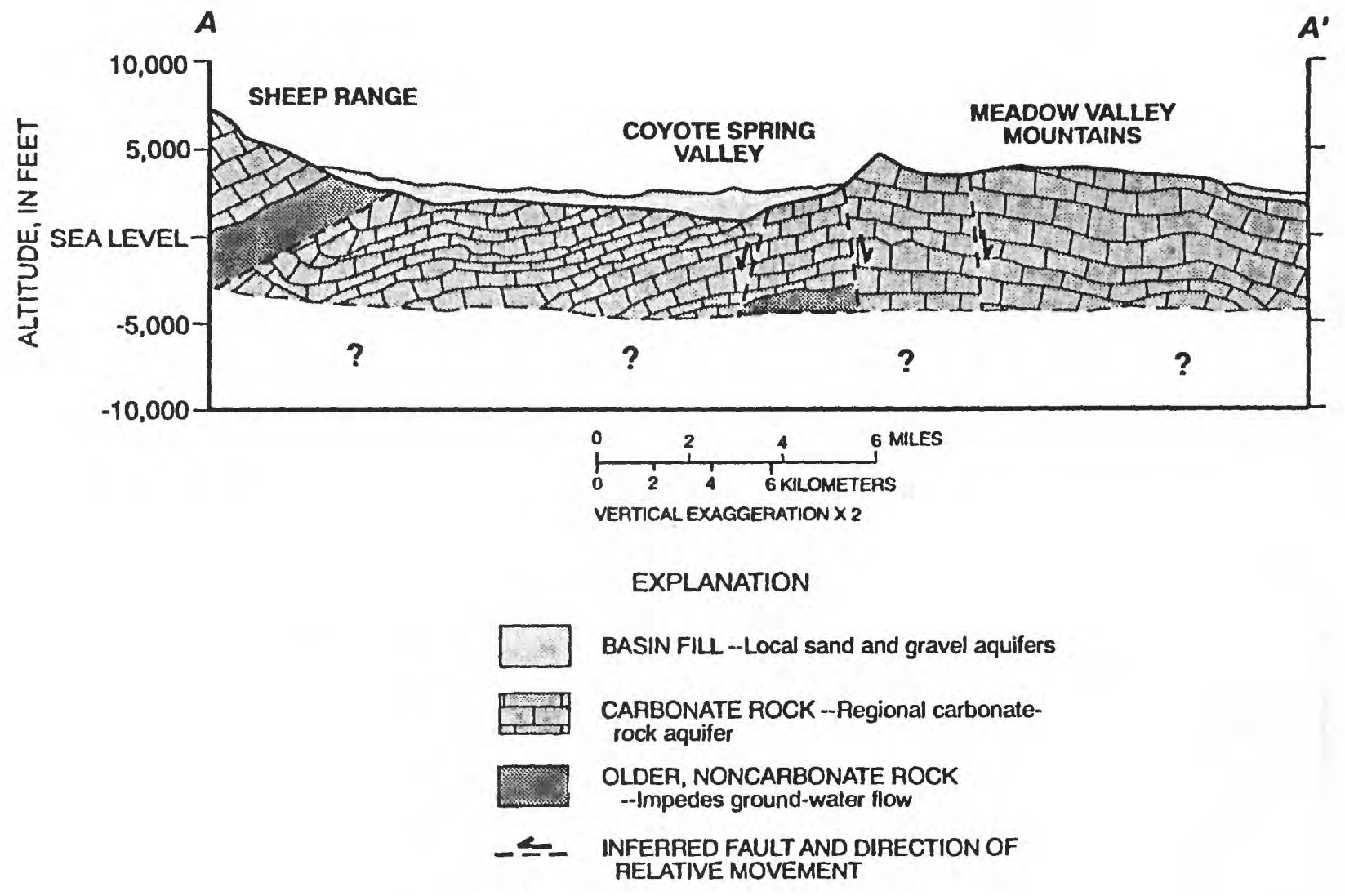

FIGURE 2. --Generalized section of hydrogeologic units in study area. 


\section{GEOPHYSICAL LOGGING METHODS}

Gamma-gamma, neutron, and acoustic transit-time logs were used to estimate the porosity and density of the carbonate-rock aquifers. In addition, three-arm caliper and natural-gamma instruments were used to identify zones of rugosity and the presence of shale or clay. Each geophysical logging instrument can indirectly estimate lithologic properties of an aquifer by responding to different physical properties of the rock. Log responses measured in the field can be related to these hydrogeologic properties through calibration to responses in lithologies of known porosities and densities.

Rugosity is the roughness of a test-well wall caused by drilling and subsequent wash-outs and can produce anomalous responses on geophysical logs. The caliper log indicates an enlarged hole diameter that causes cycle skips on the acoustic log. In some wells, rugosity is caused by the intersection of fractures with the test well and may be an indication of secondary porosity development and possible zones of increased transmissivity. Secondary porosity in carbonate-rock aquifers takes the form of fractures, solution openings, and bedding-plane voids which can be identified from the $\log$ responses. A detailed discussion of the theory of geophysical logging is beyond the scope of this report. A brief summary of each geophysical logging method used in this study follows. In this report, the gamma-gamma and neutron records are referred to as nuclear logs.

\section{Gamma-Gamma Logs}

The gamma-gamma logging method uses a decentralized side-collimated instrument that provides a continuous record of variations in electron density of the formation adjacent to the test well. The instrument is compensated for rugosity by using two sodium iodide detectors positioned at different distances from a gamma proton source. Gamma radiation emitted from a cesium- 137 source penetrates the lithologic unit surrounding the test well and is then absorbed or scattered. The detected intensity of the backscattered gamma radiation is inversely proportional to the bulk density of the surrounding material (Keys and MacCary, 1971, p. 70). Calibration of the gamma-gamma measurements was made on site using an aluminum block of density $2.7 \mathrm{~g} / \mathrm{cm}^{3}$ and a plastic block of density $1.2 \mathrm{~g} / \mathrm{cm}^{3}$. Bulk-density values were then read directly from the analog record. The gamma-gamma method can also be used to calculate total porosity of the material adjacent to the detector. From a lithologic unit of known matrix density $\left(\rho_{m}\right)$, fluid density $\left(\rho_{f}\right)$, and recorded bulk density $\left(\rho_{b}\right)$, total porosity $(\Phi)$ can be calculated by the equation (Schlumberger Limited, 1972, p. 47):

$$
\Phi=\frac{\rho_{m}-\rho_{b}}{\rho_{m}-\rho_{f}}
$$

In this study, $1.0 \mathrm{~g} / \mathrm{cm}^{3}$ was used for freshwater-density values; matrix-density values were interpolated from the neutron-density crossplot which is discussed in a following section. The radius of investigation of the gamma-gamma detector in consolidated rock is about 5 to 6 in. (Keys and MacCary, 1971, p. 73).

\section{Neutron Logs}

The backscattered neutron flux measured by the neutron instrument is strongly influenced by elastic collisions between neutrons emitted from an americium-beryllium source and nuclei of hydrogen atoms in the lithologic unit surrounding the test well (Keys and MacCary, 1971, p. 74-75). When the hydrogen concentration surrounding the neutron detector is large, as in saturated rock, most neutrons are slowed down or moderated resulting in fewer neutrons reaching the detector. The number of neutrons detected (count rate) is inversely proportional to the hydrogen content or total water-filled porosity of the unit. The radius of investigation for the neutron detector is about 12 to 24 in. for low-porosity rocks (Keys and MacCary, 
1971, p. 84). The neutron instrument used in this study was calibrated in a limestone pit where neutron count rates were recorded for rocks of known porosities and reported in apparent limestone porosity units. The neutron instrument was decentralized to reduce the effects of well diameter changes.

Bound water associated with hydrogenous materials such as shale and clay can increase apparent porosity measurements without an actual increase in porosity. A correction for shale was applied to apparent limestone porosities for the noneffective porosity of shale in zones that exhibited significant activity on the natural-gamma log. The corrected porosity value was derived by removing the noneffective porosity contribution from the apparent limestone porosity measurement (Schlumberger Limited, 1972, p. 94-95).

\section{Acoustic Transit-Time Logs}

The acoustic log records the time for an acoustic pulse to travel the shortest path from a transmitter to a receiver through the rock surrounding the well (Keys and MacCary 1971, p. 88). Wyllie and others (1958), through laboratory experiments, found that a linear relation exists between primary porosity and transit time in consolidated units with uniformly distributed porosity.

$$
\Delta t=\Delta t_{f} * \Phi+\Delta t_{m} *(1-\Phi)
$$

where:

$$
\begin{aligned}
& \Delta t=\text { transit time recorded on the acoustic log, in microseconds per foot; } \\
& \Delta t_{f}=\text { transit time of fluid, in microseconds per foot; } \\
& \Phi \quad=\text { primary porosity, in decimal percent; and } \\
& \Delta t_{m}=\text { transit time of the rock matrix, in microseconds per foot. }
\end{aligned}
$$

Apparent transit times for the rock matrix were interpolated from figures 3-5 in Schlumberger Limited (1974, p. 24); a transit time of $200 \mu \mathrm{s} / \mathrm{ft}$ was assumed for freshwater. The radius of investigation of the acoustic detector is 2 to $3 \mathrm{ft}$ for rocks having a velocity of about 25,000 ft/s (Keys and MacCary, 1971, p. 92). The acoustic transit-time instrument used in this study has two receivers with a transmitter-receiver span of 1 and $2 \mathrm{ft}$ that allowed better resolution of thin beds than provided by the gamma-gamma and neutron logs.

In carbonate rocks with fractures or secondary porosity development, the acoustic-derived porosity generally is smaller than the total porosity by an amount approaching the secondary porosity (Schlumberger Limited, 1972, p. 39). The acoustic-wave path travels through the rock matrix and around the larger openings providing transit times representative of the primary porosity. In units with well-developed secondary porosity, cycle skips can be recorded on the acoustic log. Cycle skips are anomalously long transit times caused by the missed first arrival of an acoustic signal; response is, instead, to the next detectable signal. An example of cycle skipping is seen on figure 3 near 409 and $417 \mathrm{ft}$ depths on the acoustic log. Acoustic-derived porosity values associated with cycle skips are commonly greater than total porosity derived from using the nuclear methods. The presence of lamina in a unit may also increase the acoustic-derived porosity because the recorded transit times of shale may exceed the transit time of the rock matrix (Schlumberger Limited, 1972, p. 39).

\section{Caliper Logs}

A three-arm caliper measures the average diameter of the test well (Keys and MacCary, 1971, p. 94). It records zones of rugosity caused by fractures and enlarged-hole diameters that may produce anomalous deflections on other logs. Analysis of the carbonate rock was made in zones that recorded a relatively smooth sidewall by the caliper and had a diameter near the original drill bit size. 


\section{Natural-Gamma Logs}

The natural-gamma instrument measures the activity of naturally occurring gamma radiation of a unit. Fine-grained units tend to have the highest concentrations of gamma radiation usually from potassium40, uranium-decay series, and thorium-decay series (Keys and MacCary, 1971, p. 64). Identifying clay or shale-bearing units was the principal application of the natural-gamma log in this study. Values greater than 50 counts per second (cps) were recorded in a pure shale unit from a well in carbonate rocks outside the study area. Background gamma activity measured in the carbonate rocks was extremely low, about 5 to 10 cps.

\section{INTERPRETATION OF DATA}

Representative zones were selected below the ground-water level using criteria proposed by MacCary (1978) to provide analysis of the overall lithology penetrated by each test well. The zones were chosen across intervals where the gamma-gamma, neutron, and acoustic logs had either a minimum or a maximum deflection, or traced a constant value. Fractures or enlarged-hole-diameter zones recorded by the three-arm caliper were not used. The log responses from each zone were averaged over 1.5 -ft intervals to minimize local effects. Log responses were recorded digitally at intervals of $0.5 \mathrm{ft}$ on magnetic tape and continuously on an analog strip chart. For each test well, all zones selected for analysis were in saturated rocks, because the neutron- and acoustic-log instruments require operation in water-filled wells.

The neutron-density crossplot shown in figure 4 for test well CSV-2 is widely used in the petroleum industry (Telford and Others, 1976) and recently in water-resources investigations for lithologic identification and estimates of porosity, and matrix density in carbonate sequences. Apparent limestone porosity measurements were plotted against measurements of bulk density for each zone. Each zone was then evaluated in relation to type curves of the matrix densities and associated porosities for three pure lithologies. Matrix-density values used for pure lithologies are: silica, $2.65 \mathrm{~g} / \mathrm{cm}^{3}$; limestone $2.71 \mathrm{~g} / \mathrm{cm}^{3}$; and dolomite, $2.87 \mathrm{~g} / \mathrm{cm}^{3}$. Apparent limestone porosity from each zone was corrected for lithologic mixtures by interpolating between connected porosity values on the type curves, resulting in a "true" total porosity value. Matrix-density values were determined by interpolating between two pure matrix type curves. Lithologic identification and associated porosity development were interpreted from the plotted position of each zone.

The acoustic-density crossplot for test well CE-DT-6 is used in a way similar to the neutron-density crossplot by plotting, for each zone, responses from the acoustic and the gamma-gamma logs. Zones with increasing shale content tend to plot to the right of the dolomite type curve on the acoustic-density crossplot (Raymer and Biggs, 1963).

The litho-porosity plot (M-N plot, developed by Burke and others, 1969) shown in figure 5 for test well CSV-2, was used in this analysis to detect secondary porosity development and provide additional information on the mineral composition of the rocks. This method plots two porosity-independent parameters, "M" and "N", that are calculated from responses of gamma-gamma, neutron, and acoustic logs from the following equations:

$$
\begin{gathered}
N=\frac{\Phi_{f}-\Phi_{L S}}{\rho_{b}-\rho_{f}} \\
M=\frac{\Delta t_{f}-\Delta t}{\rho_{b}-\rho_{f}} \times .01
\end{gathered}
$$


where:

$$
\begin{aligned}
& \Delta t_{f}=\text { transit time of the fluid, } 200 \text { microseconds per foot; } \\
& \Delta t=\text { transit time recorded by acoustic log, in microseconds per foot; } \\
& \rho_{b}=\text { bulk density recorded by gamma-gamma log, in grams per cubic centimeter; } \\
& \rho_{f}=\text { fluid density, } 1 \text { gram per cubic centimeter; } \\
& \Phi_{f}=\text { neutron porosity of fluid, } 100 \text { percent }(1.0 \text { for } 100 \text { percent water); and } \\
& \Phi_{L s}=\text { neutron porosity recorded by neutron log, in percent as decimal. }
\end{aligned}
$$

$\mathrm{M}$ values are multiplied by a factor of 0.01 only for graphing convenience. Three pure mineral endpoints of silica, calcite, and dolomite create a lithology triangle that represents a shale-free carbonate zone. Zones which plot above the dolomite-calcite-silica line are considered to have secondary porosity development of magnitude represented by the distance from the point to the lithology triangle (MacCary, 1978). The effects of shale or clay in the unit make the zones plot in the increasing shale region below the lithology triangle. Rugosity will also cause the zones to plot in the direction of increasing shale content (Burke and others, 1969).

\section{LITHOLOGIC PROPERTIES FROM LOG ANALYSIS}

Total depth of the test wells, depth to carbonate rock, ground-water levels, and land-surface altitudes for each site are shown in table 1. Information on the well construction and detailed lithologic logs for each well can be found in Berger and others (1988). The depth interval of the zones analyzed in each test well and the geophysical $\log$ data associated with each zone are given in table 2 . Matrix density values, total porosity estimates, and the matrix mineralogy percentages for each zone are given in table 3.

\section{Test Well CSV-2}

Test well CSV-2 (fig. 1) penetrated the Bird Spring Formation of Mississippian, Pennsylvanian, and

\begin{tabular}{|c|c|c|c|c|c|c|}
\hline $\begin{array}{c}\text { Test } \\
\text { well } \\
\text { (figure) }\end{array}$ & $\begin{array}{l}\text { U.S. Geological Survey } \\
\text { site identification }\end{array}$ & Local site designation ${ }^{2}$ & $\begin{array}{l}\text { Total } \\
\text { depth }\end{array}$ & $\begin{array}{l}\text { Depth to } \\
\text { carbonate } \\
\text { rock }\end{array}$ & $\begin{array}{l}\text { Depth to } \\
\text { ground- } \\
\text { water } \\
\text { level }\end{array}$ & $\begin{array}{c}\text { Land-surface } \\
\text { altitude } \\
\text { (feet above sea } \\
\text { level) }\end{array}$ \\
\hline CSV-2 & 364650114432001 & 219 S13 E65 28BDAC1 & 470 & 20 & 390 & 2,186 \\
\hline CE-DT-4 & 364743114533101 & 210 S13 E63 23DDDC1 & 670 & 30 & 350 & 2,173 \\
\hline CE-DT-6 & 364604114471301 & 219 S13 E64 35ACAA1 & 940 & 80 & 460 & 2,275 \\
\hline CE-VF-2 & 365227114554401 & 210 S12 E63 29DABC2 & 1,221 & 850 & 610 & 2,467 \\
\hline SHV-1 & 363308114553001 & 217 S16 E63 09DDAB1 & 920 & 250 & 830 & 2,649 \\
\hline
\end{tabular}
Permian age. Locally, the Bird Spring Formation consists predominantly of limestone and dolomite with layers of shale and sandstone (Berger and others, 1988). Longwell and others $(1965$, p. 32) report that the carbonate units of the Bird Spring Formation are commonly thin bedded, impure, and may contain chert nodules.

TABLE 1.--Test-well information and depth to ground-water level

[Depths in feet below land surface, except as indicated]

I The standard Geological Survey site identification is based on the grid system of latitude and longitude. The number consists of 15 digits. The first six digits denote the degrees, minutes, and seconds of latitude; the next seven digits denote degrees, minutes, and seconds of longitude; and the last two digits (assigned sequentially) identify the sites within a 1-second grid. For example, site 365227114554401 is at $36^{\circ} 52^{\prime} 27^{\prime \prime}$ latitude and $114^{\circ} 55^{\prime} 44^{\prime \prime}$ longitude, and it is the first site recorded in that 1 -second grid. The assigned number is retained as a permanent identifier even if a more precise latitude and longitude are later determined.

2 The local site designation is used in Nevada to identify a site by hydrographic area (Rush, 1968) and by the official rectangular subdivision of the public lands referenced to the Mount Diablo base line and meridian. Each site designation consists of four units: The first unit is the hydrographic area number. The second unit is the township, preceded by an $\mathbf{N}$ or $\mathbf{S}$ to indicate location north or south of the base line. The third unit is the range, precoded by an $\mathrm{E}$ to indicate location east of the meridian. The fourth unit consists of the section number and letters designating the quarter section, quarter-quarter section, and so on (A, B, C, and D indicate the northeast, northwest, southwest, and southeast quarters, respectively), followed by a number indicating the sequence in which the site was recorded. For example, site 210 S12 E63 29DABC2 is in Coyote Spring Valley (hydrographic area 210). It is the second site recorded in the southwest quarter (C) of the northwest quarter (B) of the northeast quarter (A) of the southeast quarter (D) of section 29, Township 12 South, Range 63 East, Mount Diablo base line and meridian. 
Caliper, acoustic, and natural-gamma logs and the depths of eight zones that were analyzed for this test well are shown in figure 3. Examination of the positions of the zones on the neutron-density crossplot in figure 4 indicates that the rock is composed of limestone with differing amounts of dolomite and silica. Zones 6 and 8 exhibit the least amount of lithology mixture (about 90 percent calcite) and have total porosity values of 1.0 and 0 percent, respectively (table 3). In contrast, zones 1 through 5 and 7 are composed of a mixed lithology and have total porosity values of 4.2 to 7.0 percent, which are greater than porosity values of typical pure limestone. Zone 3 was determined to be composed predominantly of silica and had the greatest total porosity--7.0 percent. All eight zones plot as shale on the M-N plot in figure 5 . The natural-gamma log (fig. 3 ) does not imply the presence of pure shale, but rather a shaly (or impure) carbonate rock. The combination of rugosity and the presence of shaly rock causes the zones to plot in the direction of increasing shale percentages on the M-N plot. Secondary porosity effects recorded as cycle skips were seen at 395,409 , and $417 \mathrm{ft}$ on the acoustic log (fig. 3 ) and were caused by fractures within the carbonate rock. The recorded transit times (table 2) for the eight zones, ranging from 86 to $113 \mu \mathrm{s} / \mathrm{ft}$, are greater than the range for pure carbonate rock, but are within the range typical of shaly carbonate rock. Fracture zones and lamina will also produce anomalously high transit times (cyclic skips). Bulk-density measurements for the eight zones averaged $2.63 \mathrm{~g} / \mathrm{cm}^{3}$, an indication that the carbonate rock is fractured. The estimated matrix-density values averaged $2.73 \mathrm{~g} / \mathrm{cm}^{3}$, an indication that the matrix mineralogy of the unit is predominantly calcite (limestone).

\section{Test Well CE-DT-4}

Test well CE-DT-4 (fig. 1) penetrated the Monte Cristo Limestone of the Mississippian shelf carbonate province (Stewart, 1980) and consists of limestone and minor amounts of dolomite, sandstone, and chert (Longwell and others, 1965). Locally, the Monte Cristo Limestone is a fine-grained siliceous limestone with abundant calcite-filled fissures. The well site is within a broad range-bounding fault zone that trends along the west side of the Arrow Canyon Range (Pierce and Hoover, 1986).

Seven zones were selected from the saturated interval (fig. 6) and the averaged log responses for each zone are in table 2 . The lithology of the zones is well defined by the neutron-density crossplot in figure 7. Zones 3 through 6 plot on or above the silica line because of the increased silica content probably in the form of bedded chert, in the Monte Cristo Limestone. Estimated total porosity values for these zones range from 9.9 to 18.5 percent (table 3 ). Zones 1,2 , and 7 consist predominantly of limestone with 10 to 40 percent mixture of silica. Estimated total porosity values for these zones ranged from 6.2 to 9.5 percent (table 3). The presence of silica in the carbonate rock apparently increases the susceptibility for fracturing and consequently increases the potential for porosity development. Primary or matrix porosity derived using equation 2 ranged from 3.1 to 8.9 percent. Secondary porosity development is indicated by the plotted positions of the zones on the $\mathrm{M}-\mathrm{N}$ plot in figure 8. Calculated values for secondary porosity ranged from 0.6 to 9.6 percent. The estimated matrix-density values from the seven zones are considerably lower than expected for a limestone and support the premise that a significant amount of silica, a less-dense matrix mineral than calcite, is present. 
TABLE 2.--Average geophysical log data and litho-porasity ( $M$ and $N$ ) values from test wells

[Bulk-density measurement from gamma-gamma instrument, apparent limestone porosity calculated from neutron method, and transit-time recorded by acoustic transit-time instrument. Abbreviations: $\mathrm{g} / \mathrm{cm}^{3}$, grams per cubic centimeter; litho-porosity $(\mathrm{M}, \mathrm{N})$, see text for explanation; $\mu \mathrm{s} / \mathrm{ft}$, microseconds per foot; --, no data available]

\begin{tabular}{|c|c|c|c|c|c|c|}
\hline \multirow{2}{*}{$\begin{array}{l}\text { Test well } \\
\text { and zone }\end{array}$} & \multirow[b]{2}{*}{ Depth of zone (feet) } & \multirow{2}{*}{$\begin{array}{c}\text { Bulk } \\
\text { density } \\
\left(\mathrm{g} / \mathrm{cm}^{3}\right)\end{array}$} & \multirow{2}{*}{$\begin{array}{c}\text { Apparent } \\
\text { limestone } \\
\text { porosity } \\
\text { (percent) }\end{array}$} & \multirow{2}{*}{$\begin{array}{c}\text { Acoustic } \\
\text { transit } \\
\text { time } \\
(\mu \mathrm{s} / \mathrm{ft})\end{array}$} & \multicolumn{2}{|c|}{ Litho-porosity } \\
\hline & & & & & $\mathbf{M}$ & $\mathbf{N}$ \\
\hline \multicolumn{7}{|l|}{ CSV-2 } \\
\hline 1 & $395.0-396.5$ & 2.69 & 5.3 & 113 & 0.51 & 0.56 \\
\hline 2 & $403.5-405.0$ & 2.61 & 3.9 & 87 & .70 & .60 \\
\hline 3 & $407.5-409.0$ & 2.50 & 3.7 & 86 & .76 & .64 \\
\hline 4 & $417.0-418.5$ & 2.57 & 4.7 & 98 & .65 & .61 \\
\hline 5 & $423.0-424.5$ & 2.68 & 7.2 & 100 & .60 & .55 \\
\hline 6 & $434.5-436.0$ & 2.70 & 1.2 & 107 & .55 & .58 \\
\hline 7 & $437.5-439.0$ & 2.54 & 3.2 & 92 & .70 & .63 \\
\hline 8 & $441.5-443.0$ & 2.71 & -19 & 88 & .65 & .60 \\
\hline \multicolumn{7}{|l|}{ CE-DT-4 } \\
\hline 1 & $397.5-399.0$ & 2.58 & 5.4 & 51 & 0.94 & 0.60 \\
\hline 2 & $427.5-429.0$ & 2.60 & 5.4 & 56 & .90 & .59 \\
\hline 3 & $449.0-450.5$ & 2.48 & 6.8 & 46 & 1.04 & .63 \\
\hline 4 & $528.5-530.0$ & 2.30 & 13.7 & 57 & 1.10 & .66 \\
\hline 5 & $571.0-572.5$ & 2.45 & 5.5 & 58 & .98 & .65 \\
\hline 6 & $596.0-597.5$ & 2.48 & 7.1 & 57 & .97 & .63 \\
\hline 7 & $626.0-627.5$ & 2.54 & 9.4 & 57 & .93 & .59 \\
\hline \multicolumn{7}{|l|}{ CE-DT-6 } \\
\hline 1 & $555.0-556.5$ & 2.61 & - & 52 & -- & -- \\
\hline 2 & $561.0-562.5$ & 2.57 & -- & 49 & - & - \\
\hline 3 & $576.5-578.0$ & 2.60 & - & 49 & - & -- \\
\hline 4 & $745.0-746.5$ & 2.61 & - & 53 & -- & - \\
\hline 5 & $761.0-762.8$ & 2.59 & - & 50 & -- & -- \\
\hline 6 & $798.0-799.5$ & 2.64 & -- & 49 & -. & -- \\
\hline 7 & $866.0-867.5$ & 2.63 & -- & 47 & -- & - \\
\hline 8 & $930.0-931.5$ & 2.61 & - & 51 & - & -- \\
\hline \multicolumn{7}{|l|}{ CE-VF-2 } \\
\hline 1 & $863.0-864.5$ & 2.75 & 0.1 & 99 & 0.58 & 0.57 \\
\hline 2 & $871.0-872.5$ & 2.64 & 2.2 & 87 & .69 & .60 \\
\hline 3 & $887.0-888.5$ & 2.70 & 0.1 & 64 & .80 & .59 \\
\hline 4 & $902.5-904.0$ & 2.90 & -35 & 53 & .77 & .54 \\
\hline 5 & $907.0-908.5$ & 2.89 & -25 & 45 & .82 & .54 \\
\hline 6 & $919.5-921.0$ & 2.88 & -26 & 54 & .78 & .55 \\
\hline 7 & $924.5-926.0$ & 2.80 & -06 & 44 & .87 & .56 \\
\hline 8 & $938.0-939.5$ & 2.91 & -07 & 65 & .71 & .53 \\
\hline 9 & $976.0-977.5$ & 2.91 & 0.2 & 49 & .79 & .52 \\
\hline 10 & $985.0-986.5$ & 2.90 & -04 & 64 & .72 & .53 \\
\hline 11 & $996.0-997.5$ & 2.77 & -01 & 58 & .80 & .57 \\
\hline \multicolumn{7}{|l|}{ SHV-1 } \\
\hline 1 & $833.0-834.5$ & 2.57 & 9.2 & 64 & 0.85 & 0.58 \\
\hline 2 & $836.0-837.5$ & 2.61 & 10.5 & 69 & .81 & .56 \\
\hline 3 & $842.0-843.5$ & 2.52 & 14.3 & 85 & .76 & .56 \\
\hline 4 & $846.5-848.0$ & 2.74 & 9.7 & 62 & .79 & .52 \\
\hline 5 & $852.5-854.0$ & 2.56 & 12.7 & 77 & .79 & .56 \\
\hline 6 & $864.0-865.5$ & 2.71 & 8.0 & 89 & .65 & .54 \\
\hline 7 & $872.0-873.5$ & 2.59 & 8.3 & 74 & .79 & .58 \\
\hline 8 & $880.0-881.5$ & 2.68 & 7.7 & 79 & .72 & .55 \\
\hline 9 & $890.0-891.5$ & 2.68 & 7.7 & 80 & .71 & .55 \\
\hline
\end{tabular}




\section{Test Well CE-DT-6}

Test well CE-DT-6 (fig. 1), approximately $7 \mathrm{mi}$ east of well CE-DT-4, is thought to be in a more structurally stable environment than the area around well CE-DT-4 (Douglas Muller, U.S. Geological Survey, written commun., 1986). The Bird Spring Formation (Longwell and others, 1965) penetrated at this site consists of alternating layers of limestone and silty or sandy limestone (Stewart, 1980).

Eight zones were analyzed from the section between 555 and $931.5 \mathrm{ft}$ below land surface (table 2). The caliper log and depths of the zones that were analyzed from the test well are shown in figure 9. The calibration curve for the neutron instrument used in this test well was not available. Total-porosity estimates (fig. 3) were made using equation 1 and the gamma-gamma log at a calcite (limestone) matrix density of $2.71 \mathrm{~g} / \mathrm{cm}^{3}$. The acoustic-density crossplot in figure 10 indicates that silica, dolomite, and shale are not present in detectable quantities; therefore, assuming a matrix density representative of calcite appears to be valid. Total porosity estimates derived using the gamma-gamma log range from 0.3 to 4.2 percent and reflect an unfractured carbonate rock. Examination of penetration rates for well CE-DT- 6 presented by Berger and others $(1988$, p. 41$)$ for the interval of $555-931.5 \mathrm{ft}$ shows no anomalous fast-drilling zones, which supports the conclusion that the carbonate rock is, for the most part, competent.

\section{Test Well CE-VF-2}

Test well CE-VF-2 (fig. 1) intersected a fine-grain dolomitic limestone (Ertec Western, Inc., 1981), probably of Early Devonian age (D.L. Schmidt, U.S. Geological Survey, oral commun., 1989), near $850 \mathrm{ft}$ below land surface (table 1). The well site is near the base of the low sloping alluvial fan on the east side of the northern Sheep Range. The well was originally drilled to a depth of 1,221 ft (Ertec Western, Inc., 1981); the geophysical log data analyzed are from the interval 850 to $1,000 \mathrm{ft}$.

Caliper, acoustic, and natural-gamma logs and the depths of 11 zones analyzed in this test well are shown in figure 11. The positions of the zones on the neutron-density crossplot in figure 12 indicate lowporosity carbonate rock with some porosity development in zones that are composed mainly of limestone (calcite) with smaller percentages of silica or dolomite. Negative values of apparent limestone porosity in table 2 result from the dolomitic composition of the rock and because the neutron instrument was calibrated in a limestone pit. The matrix mineralogy determined from the $\mathrm{M}-\mathrm{N}$ plot of figure 13 is dolomitic with minor amounts of silica and calcite. Zones $1,2,8$, and 10 plot as shale in figure 13 . This is caused by rugosity, not the presence of shale. The low gamma activity recorded by the natural-gamma instrument (fig. 11) supports the absence of shale. Total porosity estimated in the 11 zones ranged from 0 to 3.0 percent. Zones 5, 7, and 9 plot above the dolomite-calcite line on the M-N plot indicating secondary porosity development that probably constitutes more than one-half of the total porosity. The mineralogy that contains secondary porosity is a mixture of dolomite and calcite. The average matrix density was 2.82 $\mathrm{g} / \mathrm{cm}^{3}$, characteristic of dolomite and is in agreement with the lithologic interpretation from the crossplots. 
TABLE 3.--Matrix density, total porosity, and matrix mineral composition interpreted from analysis of geophysical logs of test wells

[Abbreviations: $\mathrm{g} / \mathrm{cm}^{3}$, grams per cubic centimeter; \%, percent; do, ditto; a, assumed matrix density of $2.71 \mathrm{~g} / \mathrm{cm}^{3}$ for limestone (calcite)]

\begin{tabular}{|c|c|c|c|}
\hline $\begin{array}{l}\text { Test well } \\
\text { and zone }\end{array}$ & $\begin{array}{c}\text { Matrix density } \\
\quad\left(\mathrm{g} / \mathrm{cm}^{3}\right)\end{array}$ & $\begin{array}{c}\text { Total porosity } \\
\text { (percent) }\end{array}$ & Matrix mineral composition \\
\hline \multicolumn{4}{|l|}{ CSV-2 } \\
\hline 1 & 2.72 & 4.6 & $60 \%$ calcite, $40 \%$ dolomite; shaly -- \\
\hline 2 & 2.74 & 4.2 & $60 \%$ calcite, $40 \%$ silica; shaly --- \\
\hline 3 & 2.67 & 7.0 & Silica with calcite \\
\hline 4 & 2.68 & 6.2 & $60 \%$ silica, $40 \%$ calcite; shaly \\
\hline 5 & 2.84 & 6.3 & $50 \%$ calcite, $50 \%$ dolomite; shaly -- \\
\hline 6 & 2.77 & 1.0 & $90 \%$ calcite, $10 \%$ dolomite; shaly -- \\
\hline 7 & 2.69 & 6.0 & Silica with calcite \\
\hline 8 & 2.76 & 0 & $90 \%$ calcite, $10 \%$ silica; shaly ---.- \\
\hline \multicolumn{4}{|l|}{ CE-DT-4 } \\
\hline 1 & 2.68 & 6.2 & $60 \%$ calcite, $40 \%$ silica \\
\hline 2 & 2.70 & 5.9 & $90 \%$ calcite, $10 \%$ silica \\
\hline 3 & 2.63 & 9.9 & Silica with calcite \\
\hline 4 & 2.57 & 18.5 & - do \\
\hline 5 & 2.59 & 10.0 & - do -.. \\
\hline 6 & 2.65 & 10.2 & - do -.... \\
\hline 7 & 2.71 & 9.5 & $90 \%$ calcite, $10 \%$ silica \\
\hline \multicolumn{4}{|l|}{ CE-DT-6 } \\
\hline 1 & $\mathbf{a}$ & 3.6 & calcite - \\
\hline 2 & $\mathbf{a}$ & 1.6 & -- do - \\
\hline 3 & $\mathbf{a}$ & 1.6 & -- do - \\
\hline 4 & $\mathbf{a}$ & 4.2 & 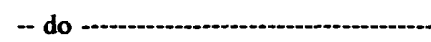 \\
\hline 5 & $\mathbf{a}$ & 2.3 & - do - \\
\hline 6 & $a$ & 1.6 & - do - - \\
\hline 7 & a & .3 & - do - - \\
\hline 8 & a & 2.9 & - do - - \\
\hline \multicolumn{4}{|l|}{ CE-VF-2 } \\
\hline 1 & 2.76 & 0.2 & $70 \%$ calcite, $30 \%$ dolomite \\
\hline 2 & 2.70 & 3.0 & $40 \%$ calcite, $60 \%$ silica \\
\hline 3 & 2.71 & .2 & $90 \%$ calcite, $10 \%$ silica \\
\hline 4 & 2.87 & 0 & $90 \%$ dolomite, $10 \%$ silica \\
\hline 5 & 2.87 & 0 & $90 \%$ dolomite, $10 \%$ calcite \\
\hline 6 & 2.86 & 0 & $80 \%$ dolomite, $20 \%$ silica \\
\hline 7 & 2.80 & .1 & $50 \%$ calcite, $50 \%$ dolomite \\
\hline 8 & 2.88 & 0 & Dolomite \\
\hline 9 & 2.91 & 0 & -- do - - \\
\hline 10 & 2.87 & 0 & - do - \\
\hline 11 & 2.76 & .1 & $60 \%$ calcite, $40 \%$ dolomite \\
\hline \multicolumn{4}{|l|}{ SHV-1 } \\
\hline 1 & 2.72 & 9.0 & $90 \%$ calcite, $10 \%$ dolomite \\
\hline 2 & 2.78 & 9.3 & $60 \%$ calcite, $40 \%$ dolomite \\
\hline 3 & 2.76 & 13.4 & 70\% dolomite, $30 \%$ silica \\
\hline 4 & 2.87 & 6.0 & Dolomite \\
\hline 5 & 2.76 & 11.7 & $70 \%$ dolomite, $30 \%$ silica \\
\hline 6 & 2.82 & 6.1 & Dolomite, shaly \\
\hline 7 & 2.73 & 8.0 & $90 \%$ calcite, $10 \%$ dolomite \\
\hline 8 & 2.79 & 6.3 & Dolomite, shaly \\
\hline 9 & 2.79 & 6.3 & - do - \\
\hline
\end{tabular}



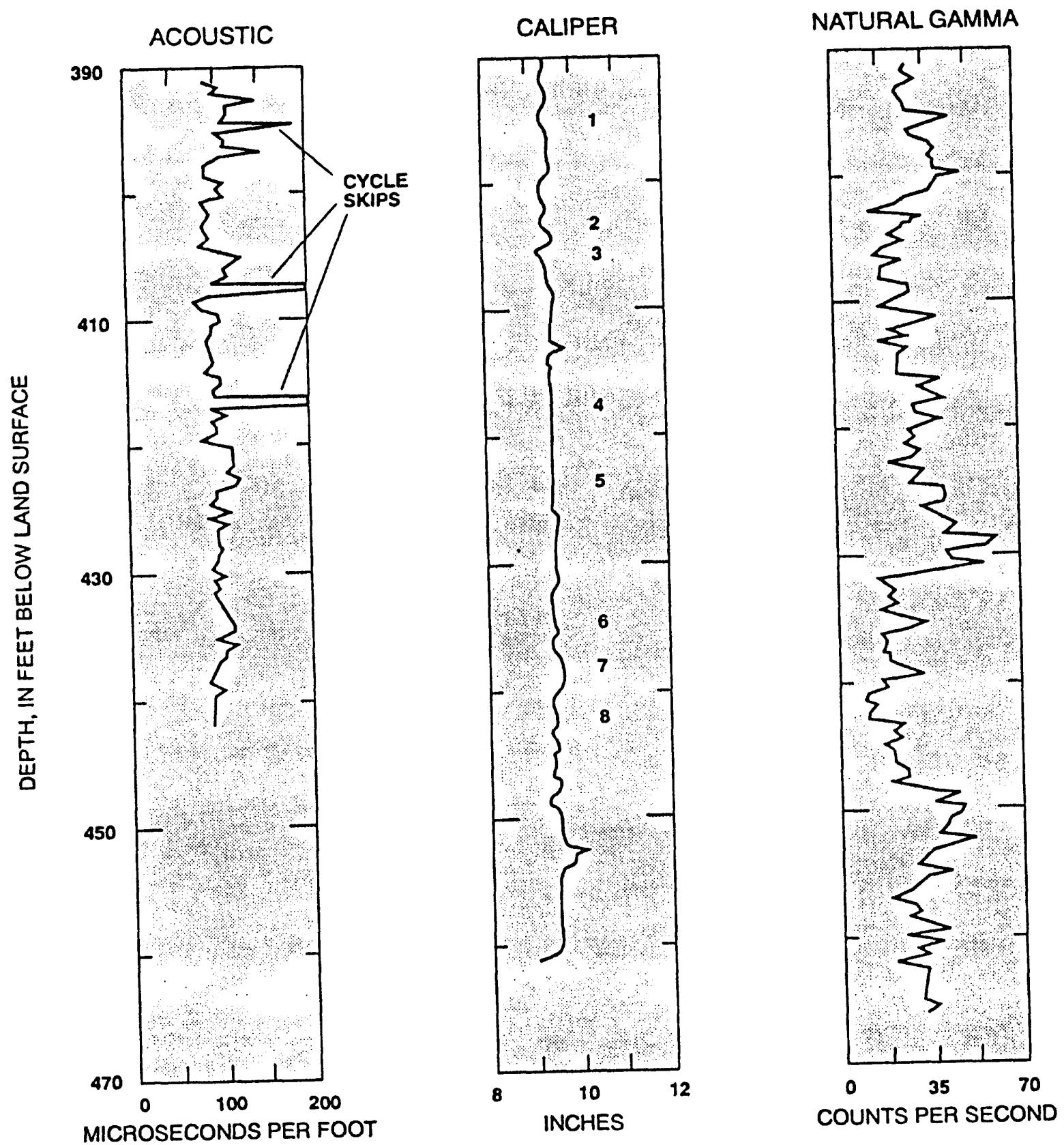

FIGURE 3. --Acoustic, caliper, and natural-gamma logs and eight zone depths (1-8) from test well CSV-2. 


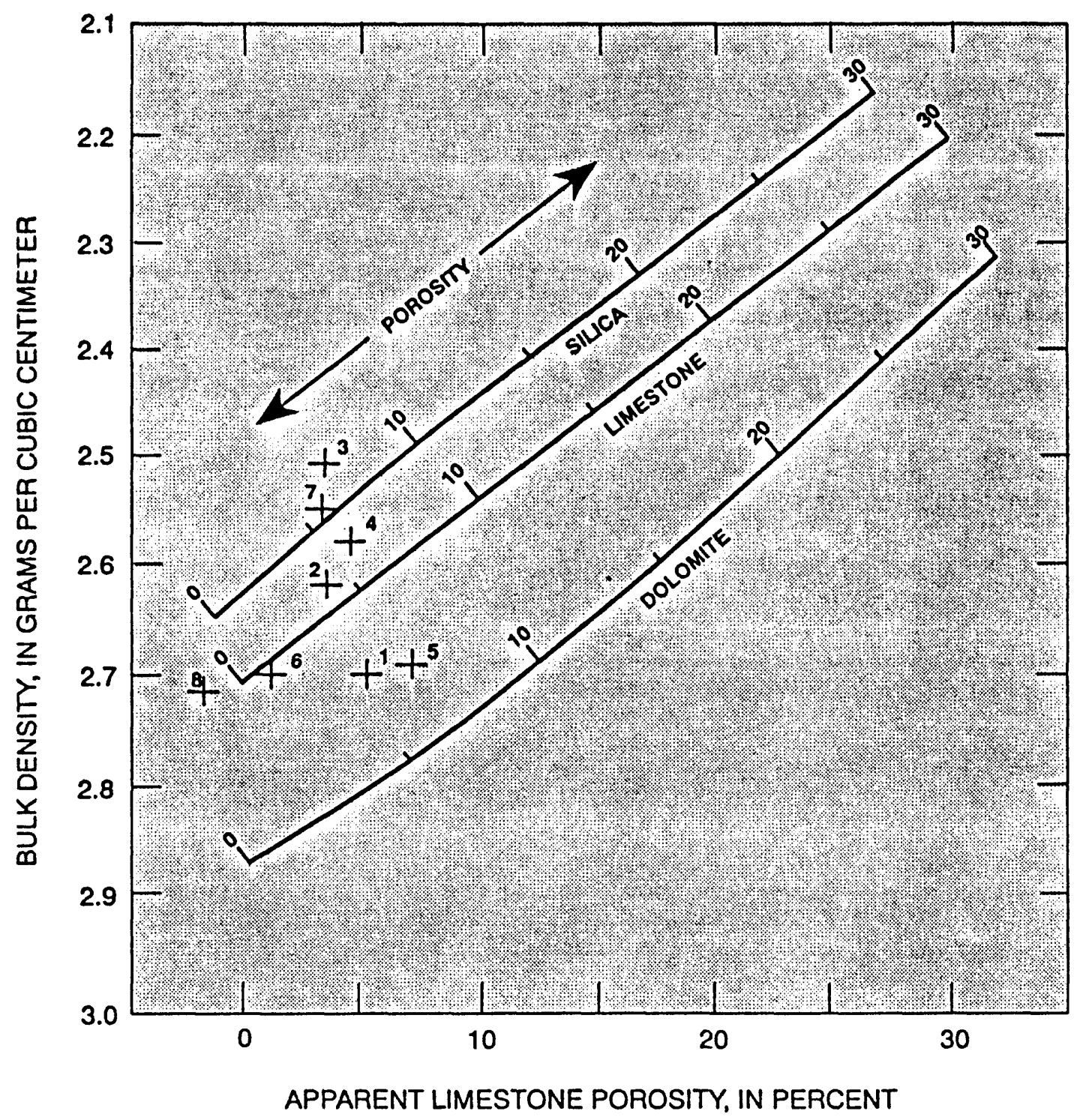

FIGURE 4. --Neutron-density crossplot of eight zones (1-8) from test well CSV-2. 


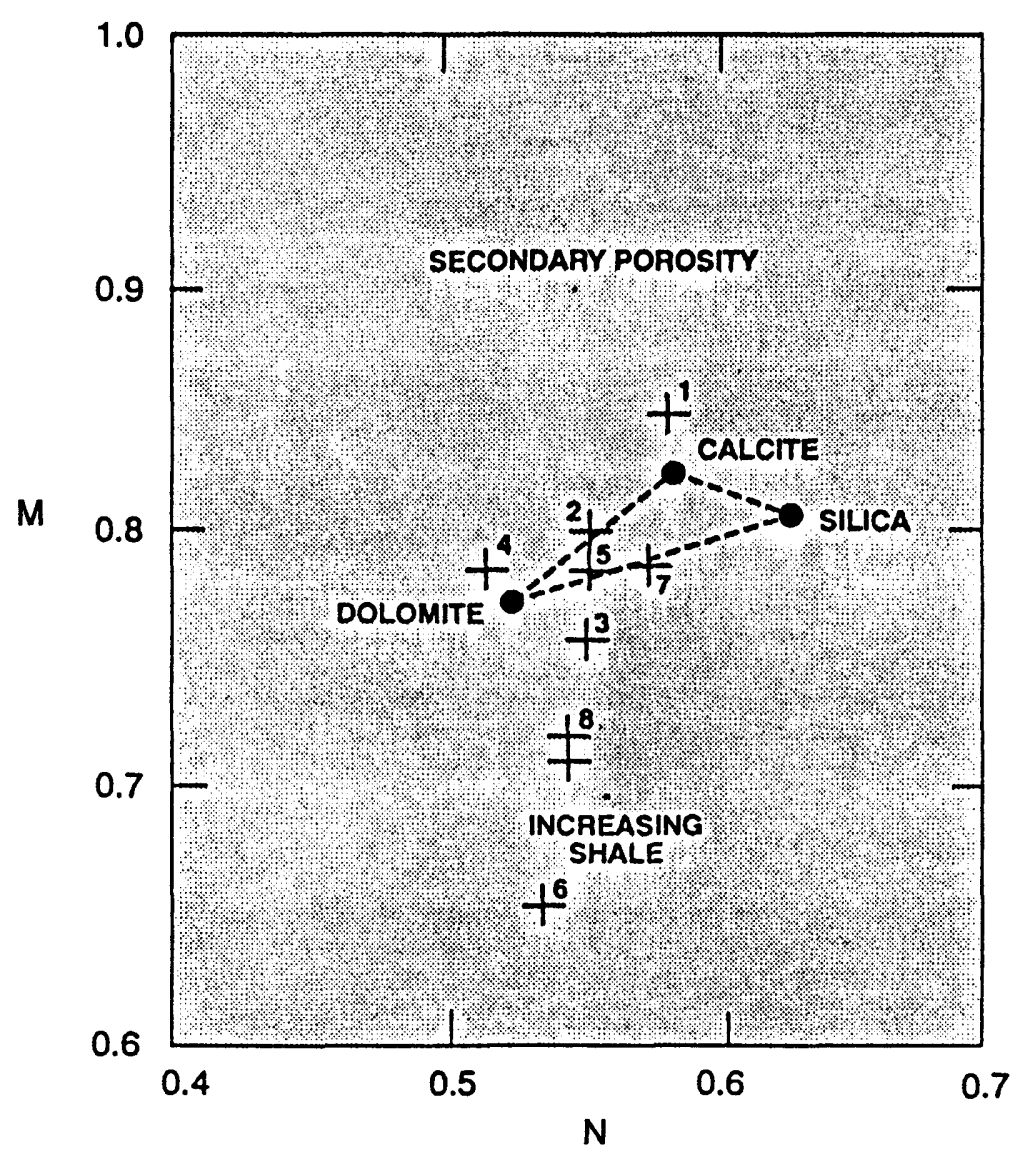

FIGURE 5. -Litho-porosity (M-N) plot of eight zones (1-8) from test well CSV-2. 


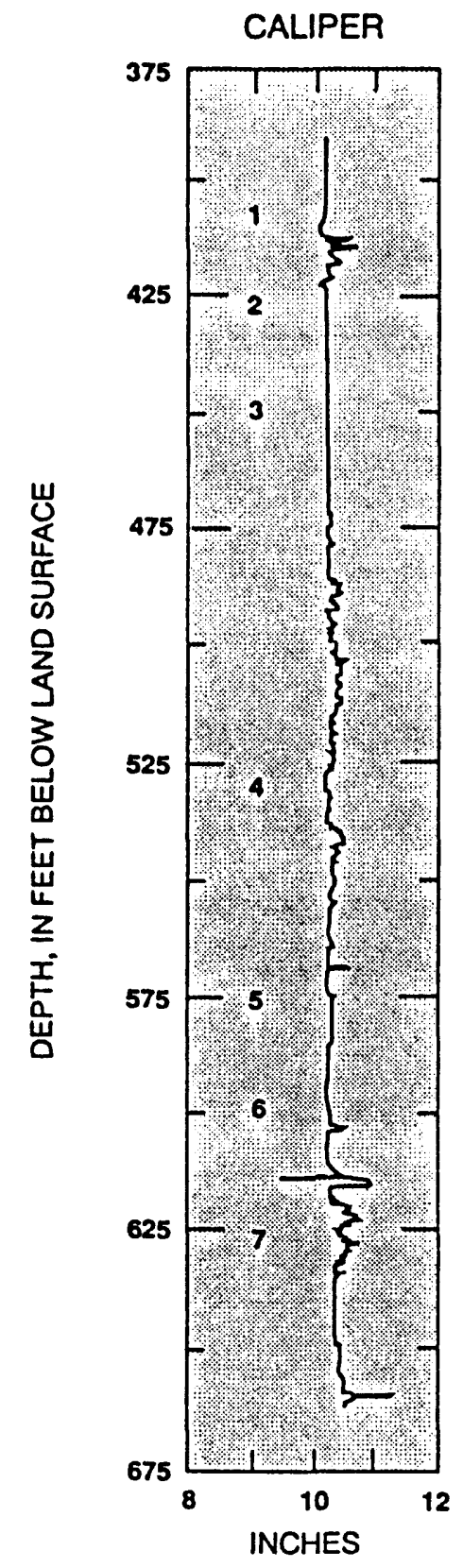

\author{
NATURAL GAMMA
}

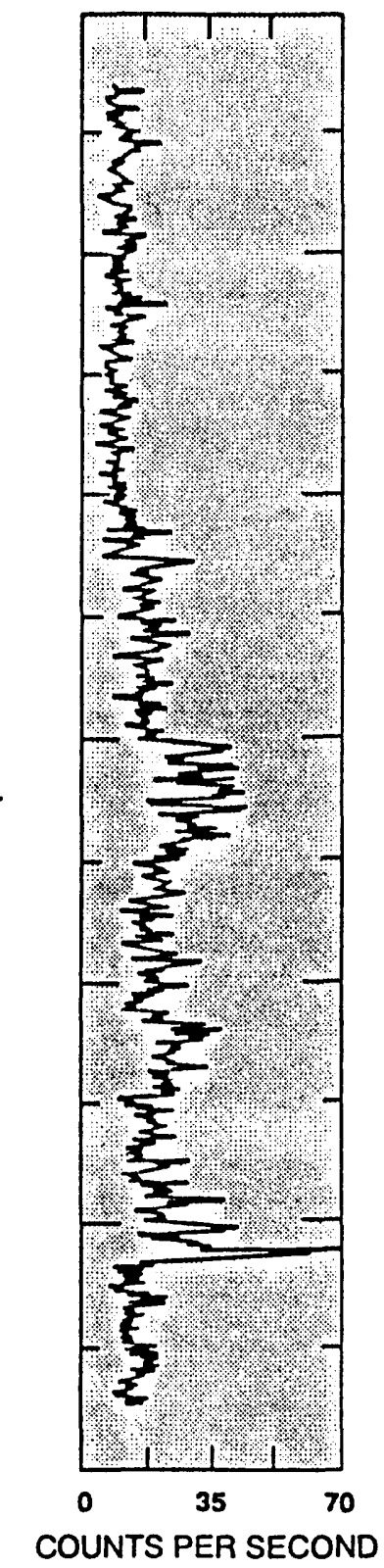

FIGURE 6. -Caliper and natural-gamma logs and seven zone depths (1-7) from test well CE-DT-4. 


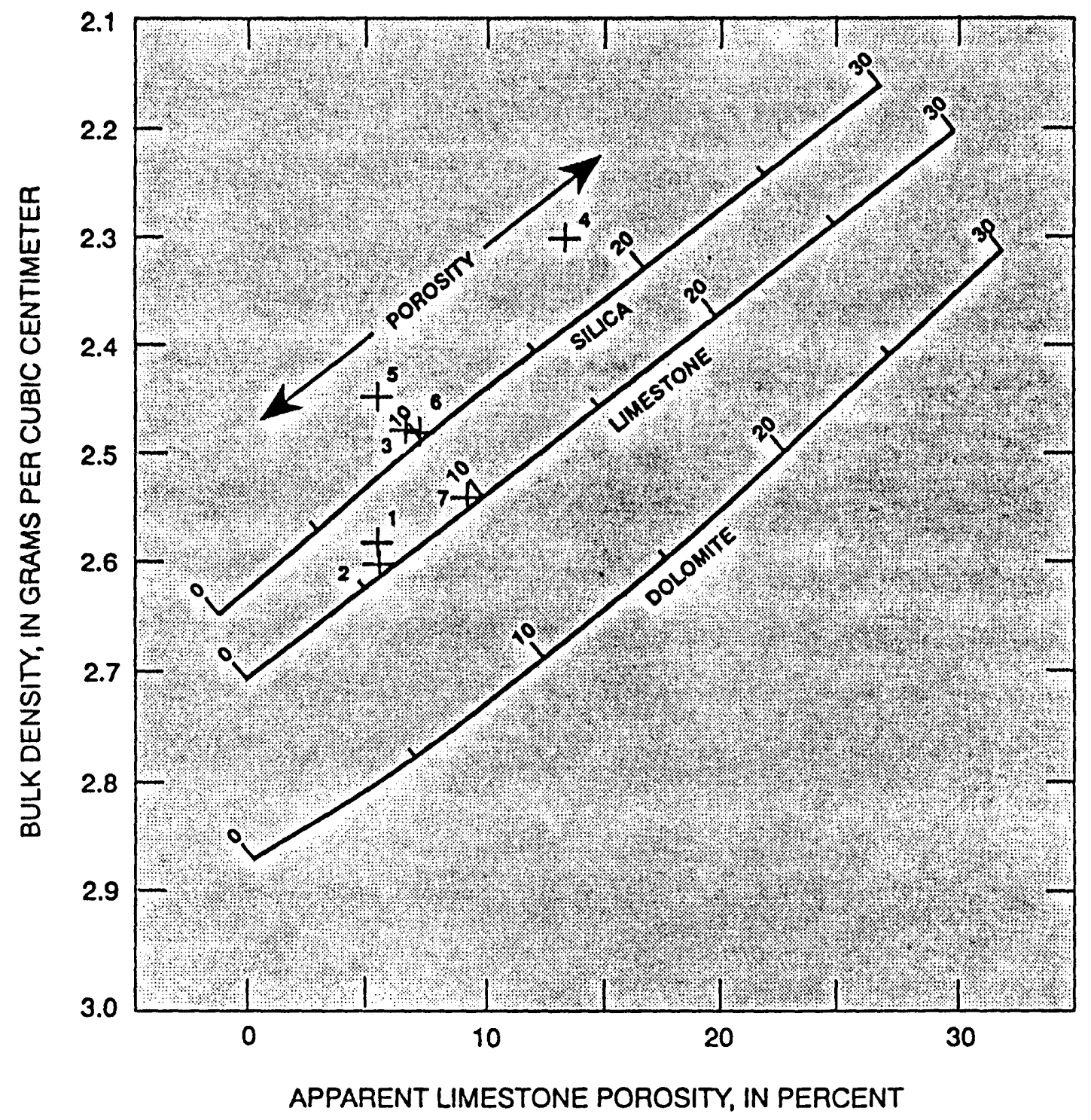

FIGURE 7. -Neutron-density crossplot of seven zones (1-7) from test well CE-DT-4. 


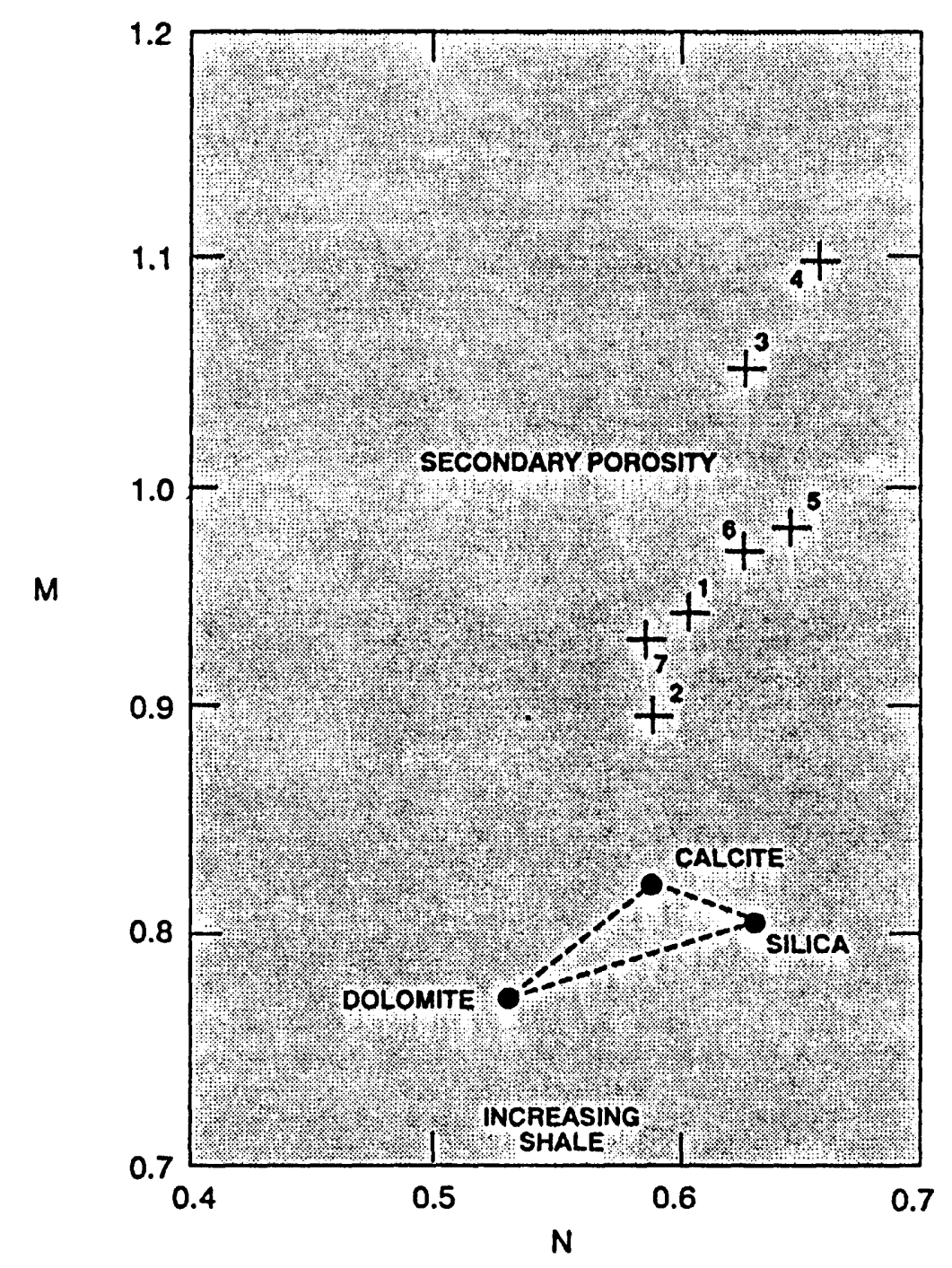

FIGURE 8. --Litho-porosity (M-N) plot of seven zones (1-7) from test well CE-DT-4. 


\section{Test Well SHV-1}

Test well SHV-1 (fig. 1) was drilled before 1958, apparently for use as a stock well, and is now abandoned. No drilling information is available. A seismic refraction survey done at the site indicated a high-velocity layer near $250 \mathrm{ft}$ below land surface. The high-velocity layer was interpreted to be carbonate rock and is in agreement with the subsequent geophysical logging results. The natural-gamma activity significantly decreases near $250 \mathrm{ft}$, as would be expected at a contact between unconsolidated material and carbonate rock (Berger and others, 1988, fig. 28). The well probably penetrated Lower Mississippian rocks.

Logs from only the lower $60 \mathrm{ft}$ of the test well were analyzed because of the great depth to water and the collapsed condition of the bottom $30 \mathrm{ft}$ of the well. Caliper and natural-gamma logs and depths of the nine zones analyzed are shown in figure 14. The caliper $\log$ in figure 14 reflects the irregularity of the well wall which was probably caused during drilling. The lithology of the carbonate rock is shown in figure 15 to be mixtures of limestone (calcite), dolomite, and silica; zone 4 is shown to be composed of pure dolomite. The natural-gamma log records gamma activity typical for a shaly carbonate rock within the study area. The plotted positions on the M-N plot (fig. 16) indicate increasing shale, but are dominated by the rugosity. Zones $4,6,8$, and 9 are composed completely of dolomite or shaly dolomite and have total porosity values that range from 6.0 to 6.3 percent; zones 1,2 , and 7 are composed predominantly of limestone (calcite) and have total porosity ranging from 8.0 to 9.3 percent. The highest estimated values of porosity are in zones with significant amounts of silica. Zones 3 and 5 are estimated to contain 30 percent silica and have total porosity values of 13.4 and 11.7 percent, respectively. Zones 1 and 4 represent matrix-lithology end members and show some secondary porosity development indicated by the plotted position above the lithology triangle on the M-N plot (fig. 16). The average of the matrix density values is $2.78 \mathrm{~g} / \mathrm{cm}^{3}$, slightly higher than calcite $\left(2.71 \mathrm{~g} / \mathrm{cm}^{3}\right)$, and reflects the presence of dolomite.

\section{Conclusions}

Geophysical logs provided in-place measurements of bulk density, neutron porosity, and acoustic transit time that were used to estimate lithologic properties of the carbonate-rock aquifer. From five test wells, 43 zones were analyzed to determine matrix density and total porosity and to identify the matrix mineralogy.

The log analyses indicated that the test wells penetrated carbonate rock that varies in composition from limestone to dolomite and mixtures of both. Calcite was the predominant matrix mineral and was detected in more than one-half of the zones analyzed ( 24 zones). Silica also was detected and is probably a major constituent of the lithologic units penetrated by test wells CSV-2 and CE-DT-4. Shales made up only a small percentage of the carbonate rock penetrated despite the indication given by the M-N plots that shales are present. Shaly or impure carbonate rock and rugosity plot as shale in the M-N plots. The natural-gamma logs, however, confirm the absence of significant amounts of shale.

Measurements of bulk density were useful in determining the overall physical characteristics of the carbonate rock. By comparing the estimated matrix density with the measured bulk density in a particular zone, a qualitative determination could be made of the degree of fracturing in the rock. In general, the measured bulk densities were less than the estimated matrix densities, indicating the presence of impure carbonate rock and fractures. The average of the bulk-density measurements was $2.65 \mathrm{~g} / \mathrm{cm}^{3}$; the average of the matrix-density estimates was $2.76 \mathrm{~g} / \mathrm{cm}^{3}$.

Total porosity values estimated from the neutron-density crossplots ranged from 0 to 18.5 percent. The average total porosity from all 43 zones was 4.7 percent. In test well CE-DT-4, zones intepretated to be composed almost completely of silica (with some calcite) had an average total porosity of about 12 percent. Estimates of secondary porosity made from the M-N plot for test well CE-DT-4 ranged from 0.6 to 9.6 percent. 


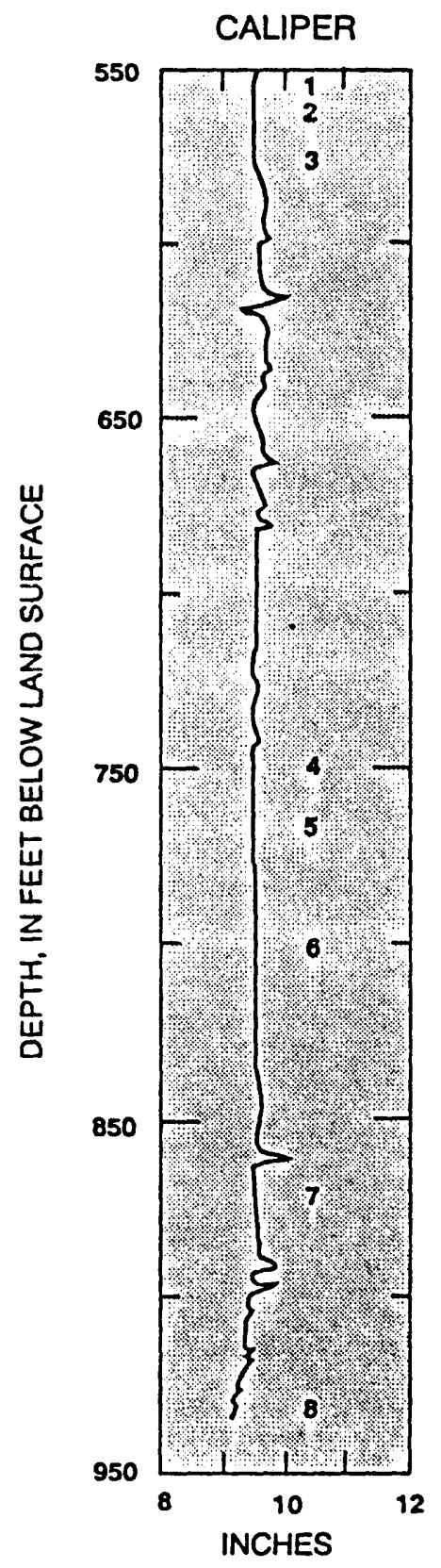

FIGURE 9. --Caliper log and eight zone depths (1-8) from test well CE-DT-6. 


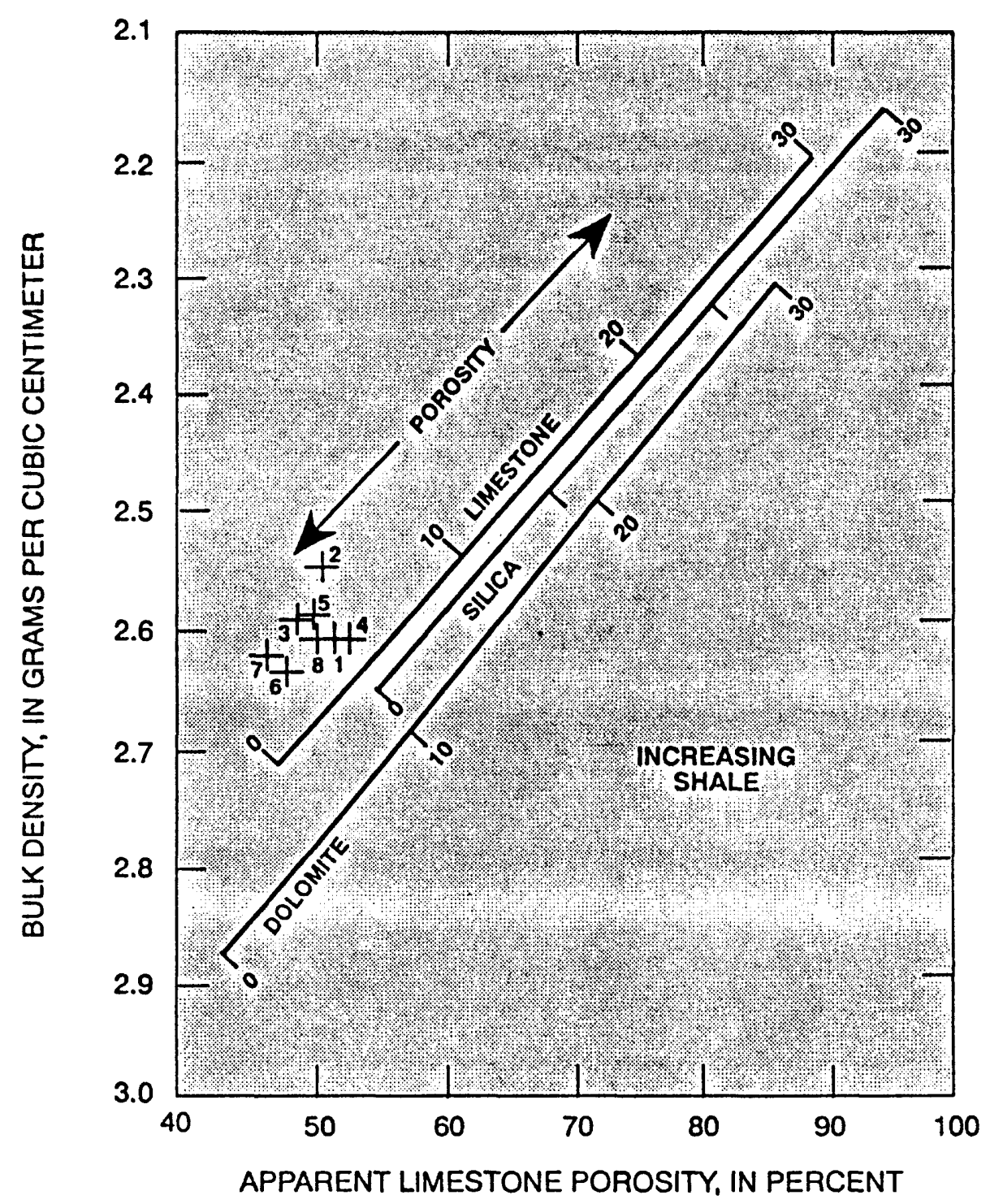

FIGURE 10. --Acoustic-density crossplot of eight zones (1-8) from test well CE-DT-6. 

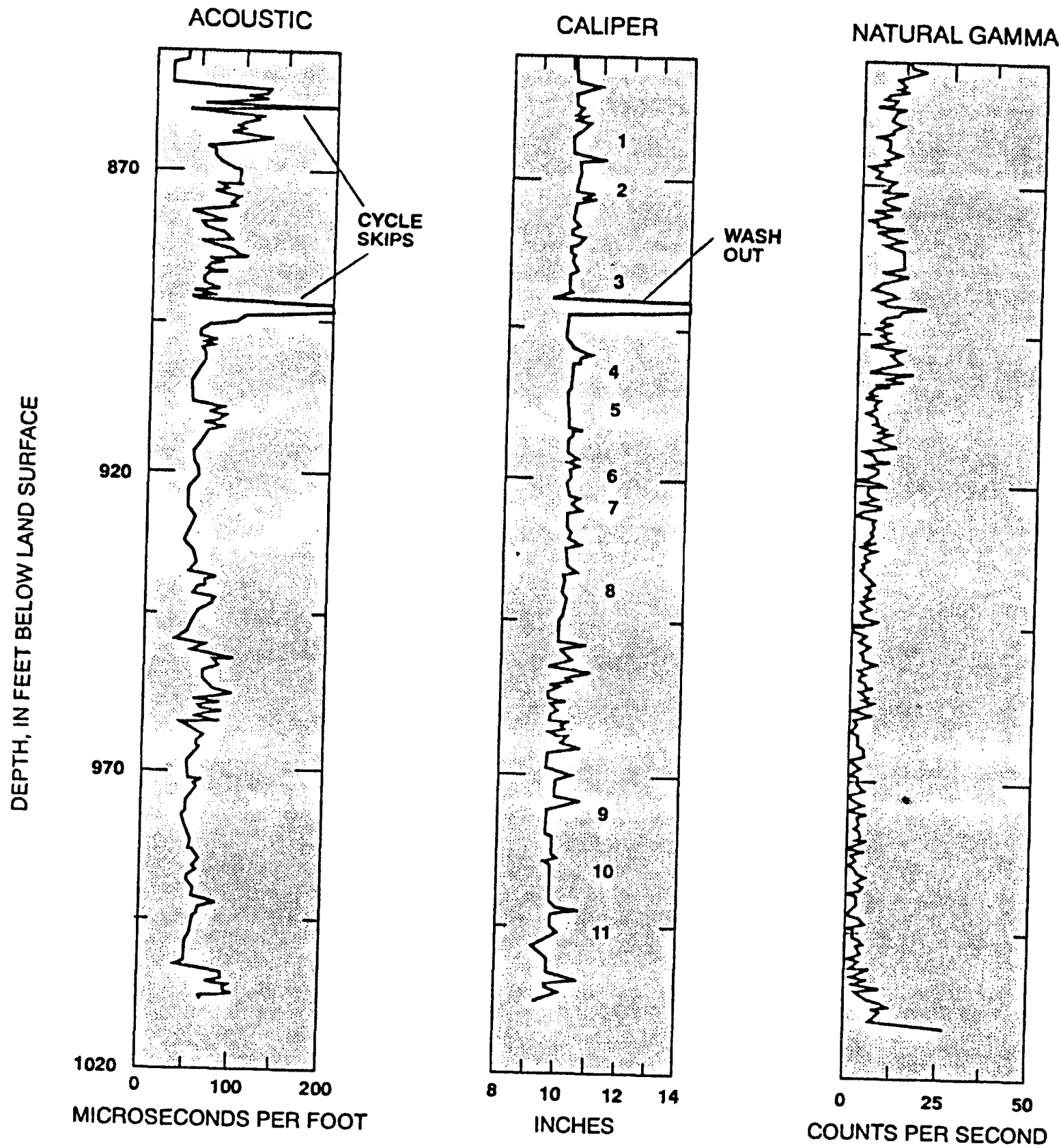
FIGURE 11. -Acoustic, caliper, and natural-gamma logs and eleven zone depths
$(1-11)$ from test well CE-VF-2. 


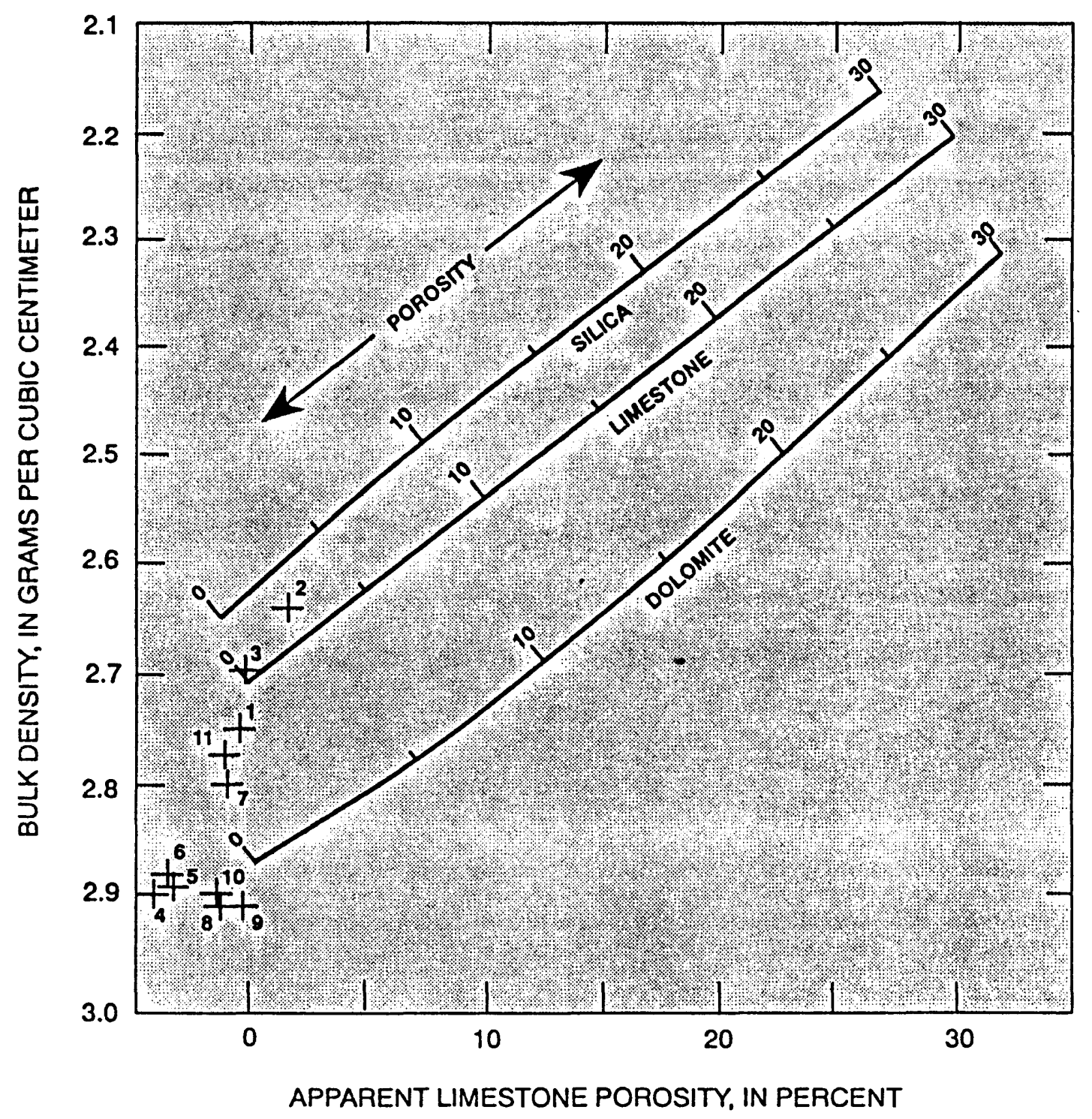

FIGURE 12. -Neutron-density crossplot of eleven zones (1-11) from test well CE-VF-2. 


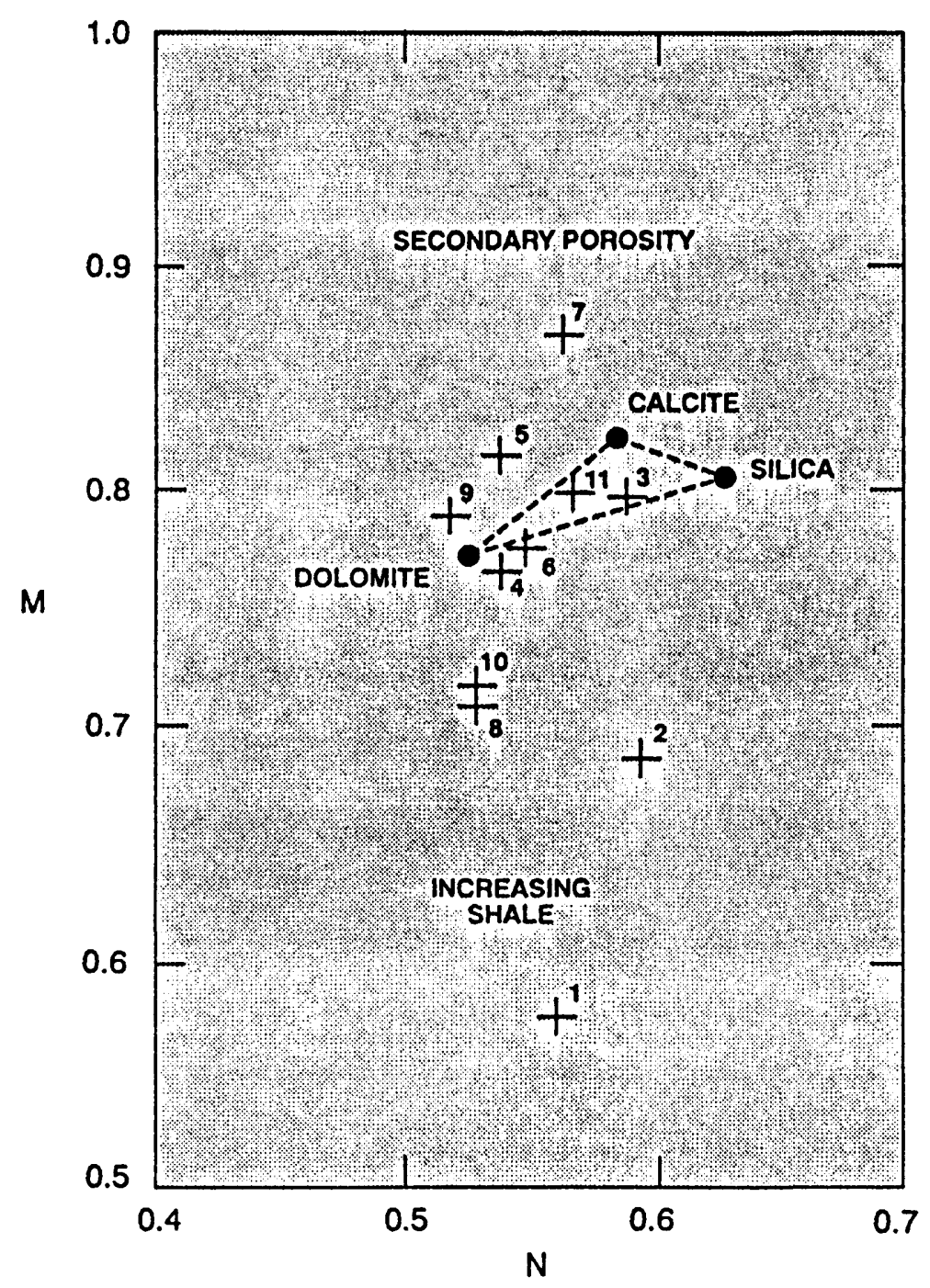

FIGURE 13. -Litho-porosity (M-N) plot of eleven zones (1-11) from test well CE-VF-2. 


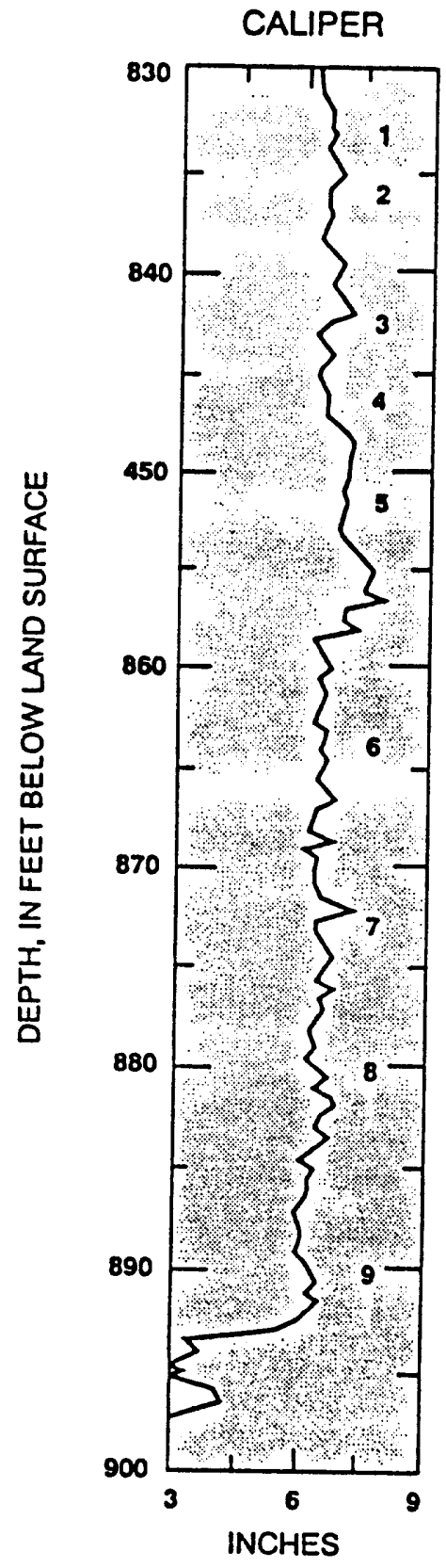

NATURAL GAMMA

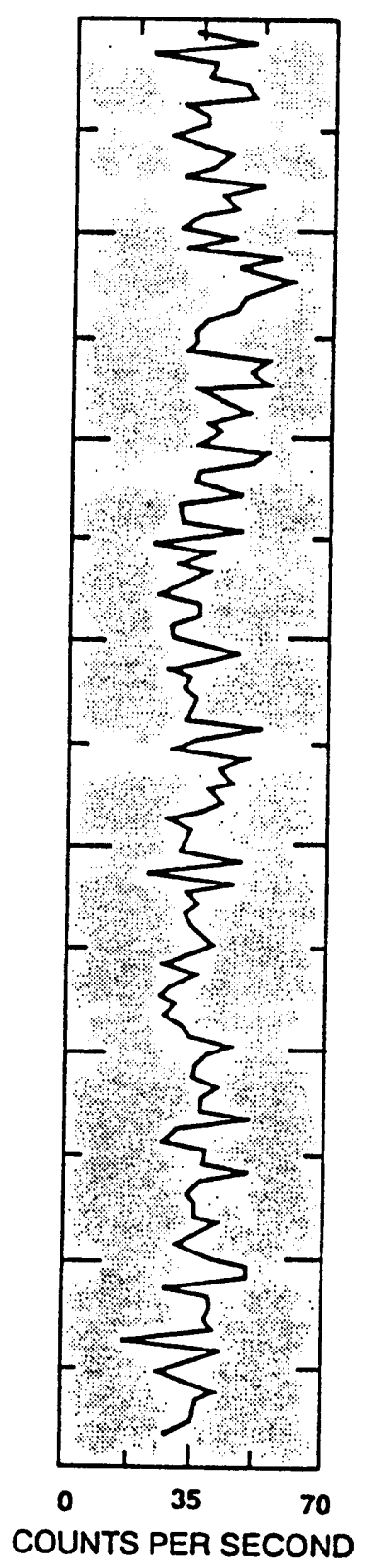

FIGURE 14. - Caliper and natural-gamma logs and nine zone depths (1-9) from test well SHV-1. 


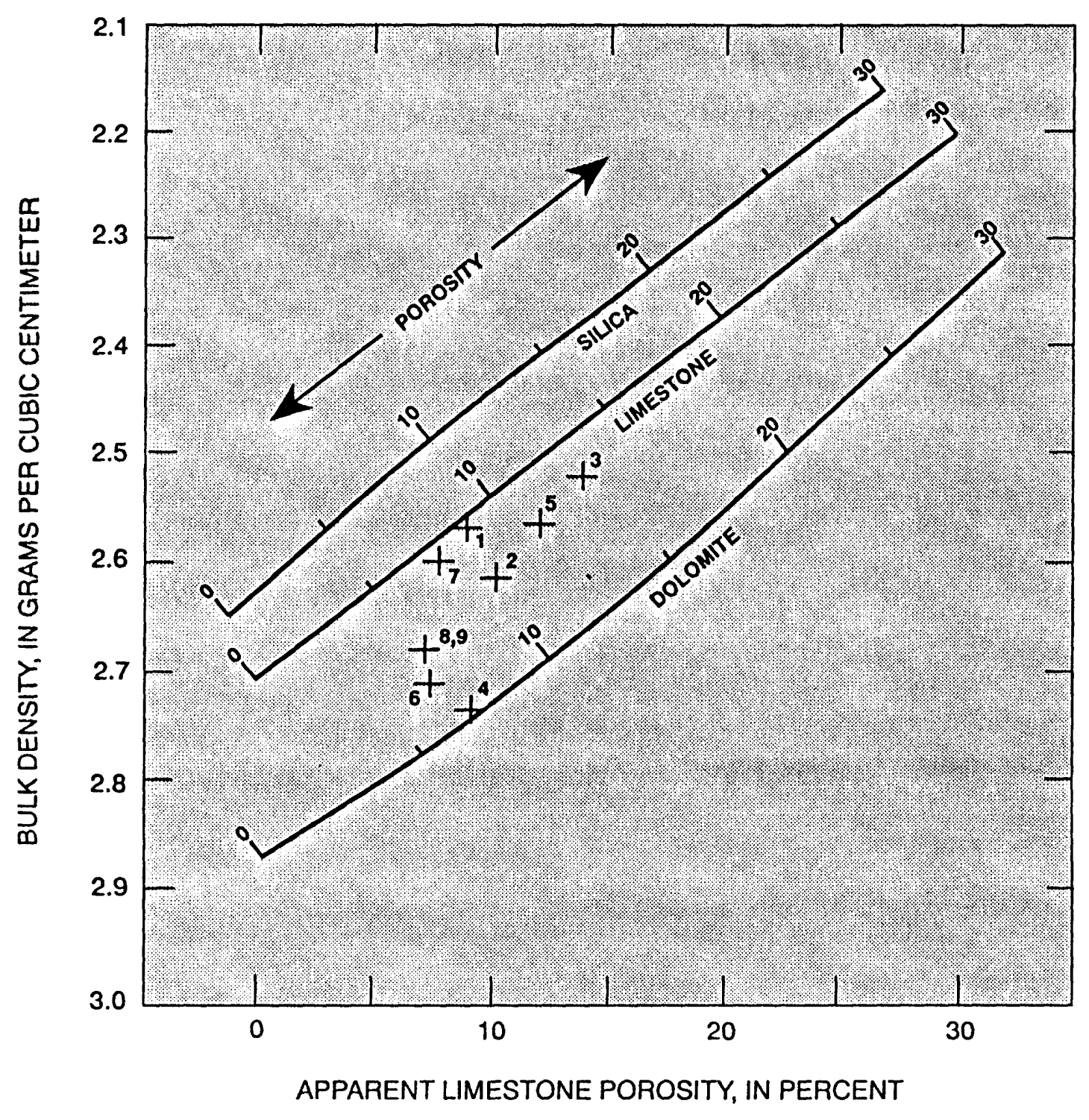

FIGURE 15. -Neutron-density crossplot of nine zones (1-9) from test well SHV-1. 


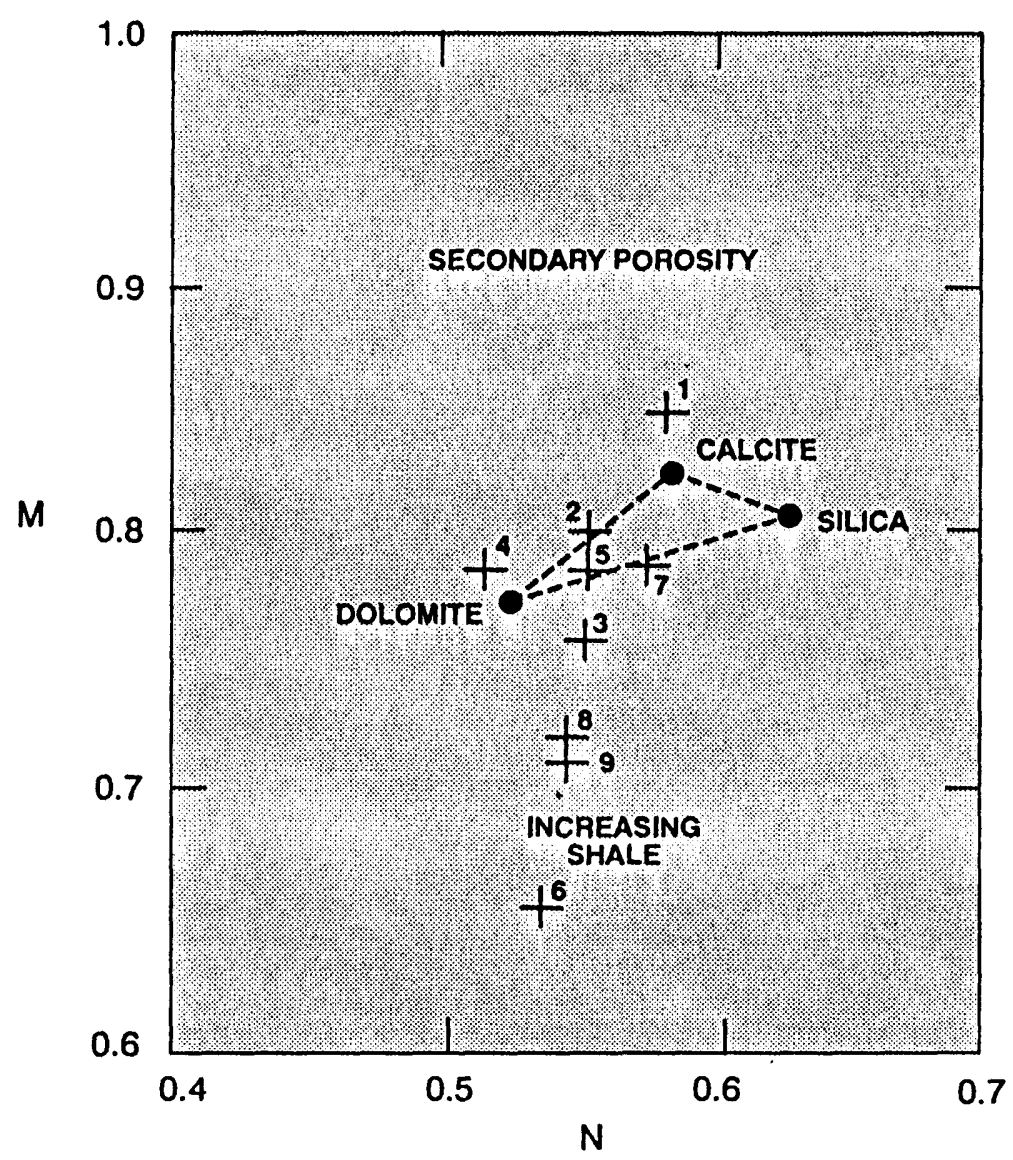

FIGURE 16. -Litho-porosity (M-N) plot of nine zones (1-9) from test well SHV-1. 


\section{REFERENCES CITED}

Berger, D.L., Kilroy, K.C., and Schaefer, D.H., 1988, Geophysical logs and hydrologic data for eight wells in the Coyote Spring Valley area, Clark and Lincoln Counties, Nevada: U.S. Geological Survey Open-File Report 87-679, 59 p.

Burke, J.A., Schmidt, A.W., and Campbell, R.L., 1969, The litho-porosity cross plot: Log Analyst, v. 10, no. 3, p. $25-43$.

Dettinger, M.D., 1987, Influence of Tertiary-age extensional tectonics on present-day regional ground-water flow and discharge in southern Nevada and vicinity: Geological Society of America Abstracts with Programs, v. 19 , no. 6, p. $371-372$.

Ertec Western, Inc., 1981, Water resources program, results of regional carbonate aquifer testing, Coyote Spring Valley, Nevada: Long Beach, Calif., Department of the Air Force, MX Siting Investigation Water Resources Report E-TR-57, 190 p.

Hewett, D.F., 1931, Geology and ore deposits of the Goodsprings quadrangle, Nevada: U.S. Geological Survey Professional Paper 162, 172 p.

Keys, W.S., and MacCary, L.M., 1971, Application of borehole geophysics to water-resources investigations: U.S. Geological Survey Techniques of Water-Resources Investigations, Book 2, Chapter E1, 126 p.

Longwell, C.R., Pampeyan, E.H., Bowyer, Ben, and Roberts, R.J., 1965, Geology and mineral deposits of Clark County, Nevada: Nevada Bureau of Mines Bulletin 62, 218 p.

MacCary, L.M., 1978, Interpretation of well logs in a carbonate aquifer: U.S. Geological Survey Open-File Report 78-88, 30 p.

Pierce, H.A., and Hoover, D.B., 1986, Results of natural-source electromagnetic methods for ground water studies near Las Vegas, Nevada: Surface and Borehole Geophysical Methods and Ground Water Instrumentation Conference and Exposition, National Water Well Association, Denver, Colorado, October 1986, Proceedings, p. 354-367.

Raymer, L.L., and Biggs, W.P., 1963, Matrix characteristics defined by porosity computations: Society of Professional Well Log Analysts, 14th annual Logging Symposium, Lafayette, LA., May 1963 Transactions, p. A1-A21.

Rush, F.E., 1968, Index of hydrographic areas, Nevada: Nevada Division of Water Resources, Information Report 6, $38 \mathrm{p}$.

Schlumberger Limited, 1972, Log interpretation--volume I-principles: Schlumberger publication, $113 \mathrm{p}$.

-----1974, Log interpretation--volume II-applications: Schlumberger publication, $116 \mathrm{p}$.

Stewart, J.H., 1980, Geology of Nevada--a discussion to accompany the geologic map of Nevada: Nevada Bureau of Mines and Geology, Special Publication 4, $136 \mathrm{p}$.

Telford, W.M., Geldart, L.P., Sheriff, R.E., and Keys, D.A., 1976, Applied Geophysics; University of Cambridge, Cambridge University Press, 860 p.

Tschanz, C.M., and Pampeyan, E.H., 1970, Geology and mineral deposits of Lincoln County, Nevada: Nevada Bureau of Mines Bulletin 73, $187 \mathrm{p}$.

Wyllie, M.R.J., Gregory, A.R., and Gardner, G.H.G., 1958, An experimental investigation of factors affecting elastic wave velocities in porous media: Geophysics, v. 23, no. 3, p. 459-493. 